\title{
Spatial variation in energy attitudes and perceptions: evidence from Europe
}

Nazmiye BALTA-OZKAN ${ }^{\mathrm{a} *}$ and Julie LE GALLO ${ }^{\mathrm{b}}$

a School of Energy, Environment and Agrifood, Cranfield University, Cranfield, Bedfordshire, MK43 0AL, United Kingdom; E-mail: n.ozkan@ cranfield.ac.uk

b Université Bourgogne Franche-Comté, UMR1041 CESAER, INRA, AgroSup Dijon, F-21000; E-mail : julie.le-gallo@agrosupdijon

\begin{abstract}
:
Driven by socio-economic processes, the influence of spatial factors on household energy related attitudes and perceptions is largely neglected in the literature. This paper analyses the extent to which energy perceptions and attitudes vary across different geographical contexts in Europe. We use representative Eurobarometer survey data to analyze how social conceptions of important energy issues, Europe's future energy priorities, and future energy system characteristics are shaped by rural, small urban, and large urban contexts. Using binary and ordered probit models, we find that householders in large and small areas are less likely to think of energy as a nationally important issue compared to their rural counterparts. Large city residents are less likely to think that renewables will play a significant role in the future energy system. Residents of large urban areas are more likely than those in rural areas to think that national energy policy should be centred on protecting the environment, guaranteeing a continuous supply of energy, and less around guaranteeing low prices for consumers.
\end{abstract}

Key words: energy attitude; energy geography; urban energy; rural energy; energy perception

\footnotetext{
* Corresponding author: E-mail: n.ozkan@cranfield.ac.uk; Tel: +44 1234 750111, Fax: +44 1234 752971.
} 


\section{Introduction}

In the context of rising household energy demands [1], concerns for energy security, threat of climate change, and uncertainties in the price of energy (the so-called 'energy trilemma', [2]) require transformation of the ways in which energy is produced, delivered and consumed. Householders can play significant roles towards this transformation by undertaking energy efficiency actions, adopting low carbon technologies or moving from consumers to 'prosumers' ${ }^{2}$. However, built environment (such as sparse settlements or different land uses) and infrastructure characteristics as well as institutional structures can facilitate or hinder the formation and carrying out of sustainable energy practices and behaviours on a daily basis. While academic literature is contentious on whether sustainable living can be achieved via changes in social practices and/ or individual behaviours [3-5], it is across space that both social practices are ordered [6] and economic motives come to life. Despite a vast literature highlighting the influence of social, cultural and institutional contexts [7], the role of spatial factors on household energy behaviours and attitudes is overlooked.

Some recent studies, using aggregate data sets, document differences in energy consumption across urban and non-urban areas [8,9]. Hori et al. [10] are among few exceptions noting how different lifestyles between rural and urban areas can affect technological choices and uptake of energy efficiency measures. However, in addition to shaping behaviours and lifestyles, built environment also influences densities of social and information networks, which are shown to play significant roles on the adoption of low carbon technologies [11-13].

\footnotetext{
2 Prosumers also includes consumers who produce their own power from a range of different onsite generators (e.g. diesel generators, combined heat-and-power systems, wind turbines, and PV systems) [63].
} 
Yet, not only does the existing literature ignore the role of spatial factors on energy attitudes and perceptions, but also most of the literature on energy behaviours is based on small sample sizes within a single country context [14-16]. Moreover, the differences in the types of technologies and behaviours assessed, explanatory variables, and methods used, along with their temporal and geographical scales make cross-study comparison of the findings difficult [17]. As a result, the robustness of these findings across different countries, using large surveys, is yet to be achieved, necessary for generating stronger evidence [18].

Another factor that is important for influencing public behaviour towards energy efficient behaviours is information provision [19,20]. In a recent study, Craig [21] reveals how consumers' awareness of energy efficiency programmes influence their decision to participate. It is highlighted that awareness of a topic would enable forming related attitudes and perceptions, followed by planning to behave accordingly [the so-called theory of planned behaviour, 22]. Beyond utility companies, the literature is very scarce on the level of trust in the source of information [23]. More specifically, the analysis of which institutions the public trusts for energy related information in the European context and how this might vary across different geographical contexts is neglected. Similarly, it has been overlooked whether and how the public's priorities on energy related matters correspond to the pillars of European energy policy i.e. decarbonisation, security of supply, and affordability. As low carbon transitions will introduce another layer of geographical heterogeneity $[24,25]$ on top of existing socio-economic differences, it is imperative for geographers and planners to examine how today's economic and energy relations will be reshaped and what future possibilities in terms of economic growth, equality and efficiency might emerge. 
The present study contributes to existing knowledge in two ways. First, it develops a conceptual framework to explain why attitudes and perceptions are likely to differ in rural, small urban and large urban areas. The research thus far has focused on cities' roles in driving transition to a low carbon economy [26]. By focusing on end users' conceptions and perceptions of energy related matters beyond cities to include rural areas, we offer unexplored avenues for future research. Secondly, we then test empirically the nature and scope of these differences using a large European survey data with nearly 16,000 observations. We employ binary and ordered probit regression models with country fixed effects. Our results highlight that urban householders are less likely to think of energy as a nationally important issue compared to their rural counterparts. On the other hand, large city residents are less likely to perceive renewables to play a significant role in the future energy system. Compared to rural residents, they are more likely to prioritize national energy policy on protecting the environment, guaranteeing a continuous supply of energy, and less around guaranteeing low prices for consumers.

The paper is structured as follows: Section 2 contextualizes energy in a spatial context. Section 3 presents the methods and data used in the analysis. The results of the econometric analysis are presented in Section 4. A discussion of the results is provided in Section 5 while the last section is devoted to conclusions.

\section{Energy in a spatial context}

By drawing from the literature on the analysis of energy consumption patterns and uptake of low carbon technologies, this study suggests that built environment characteristics, land constraints, densities of social and information networks, and 
visibility of energy system infrastructure ${ }^{3}$ will lead to different energy attitudes and perceptions across rural, small urban and large urban areas for empirical testing 4 . These factors will not only generate differences between these geographical areas but also be laid on top of existing socio-economic differences within them (Figure 1).

\section{[insert Figure 1]}

Figure 1. Conceptual model of spatial factors influencing energy attitudes and perceptions

Cutting across numerous disciplines from environmental psychology, sociology, economics to engineering, along with different research methods and techniques [for a recent review, see 27], the study of domestic energy consumption and management is quite broad. In this study we limit our attention to studies that use quantitative methods to explain energy related attitudes, perceptions and behaviours.

A significant number of studies ignore the spatial context where individuals are located and focus on the influence of socio-economic factors. Sardianou [28] highlights the importance of income and family size in explaining differences for undertaking energy conservation activities. A recent cross-country analysis, based on 5,000 observations from across 11 countries in Europe, reports different motivations to undertake energy efficiency and conservation activities between families with young children versus those with high share of elderly population [17]. While the former are largely influenced by environmental concerns, the latter are driven by a desire for financial savings with lower levels of technology adoption. Another study,

\footnotetext{
${ }^{3}$ Conceptually we recognize the importance of institutional context in deriving these differences as well. However, given the quantitative nature of the dataset and lack of relevant variables in it, this wasn't included in the analysis.

4 Throughout the paper, we use large cities, large urban areas and large urban communities interchangeably, unless otherwise stated. As discussed in detail in the next section, some attributes on energy saving behaviours were included as explanatory variables in the estimation.
} 
focusing on nine OECD countries with a sample of over 9,000 observations, analyses whether environmental concerns have an effect on reducing demand for energy and undertaking efficiency investments [29]. The authors report that environmentally more conscious householders are more likely to reduce their energy demand and install energy efficiency retrofits. On the other hand, high-income households tend to be less concerned about environmental problems and tend to curtail less, but are more likely to invest in energy efficiency. Using binary probit regression models, Sardianou and Genoudi [15] reveal that middle-aged and highly educated people are more willing to adopt renewable energy sources whilst marital status and gender do not play statistically significant roles. In addition, Karytsas and Theodoropoulou (2014) highlight that public awareness of renewable energy sources can contribute to the acceptance of renewable energy.

Yet, built environment characteristics and land constraints such as housing densities, types of buildings, provision of amenities are shown to influence demands for energy. Shammin et al. [8] report that suburban and rural living is $17-19 \%$ more energy intensive than urban living in the U.S. Nichols and Kockelman [9] differentiate between embodied and operational (day-to-day) types of energy demands and show that suburban neighborhoods — characterized by detached single-family homes consume $320 \%$ more embodied energy than a densely developed neighborhood consisting mostly of low-rise- apartments and duplexes. Further results from this study show that day-to-day activities consume $150 \%$ more energy in the former than the latter and that suburban areas consume $160 \%$ more total life-cycle energy (per capita) than urban areas. The influence of geography on energy consumption patterns has been reported for Europe as well. In the UK, Druckman and Jackson [30] highlight the key variables of type of dwelling, tenure, household composition, 
income and rural/urban location for driving different energy consumption patterns. Wiedenhofer et al. [31] analyse the effect that the influence of urban form, income and demographics have on energy consumption patterns in Austria by combining spatially resolved household expenditure data with an input-output model. Results show that differential expenditure patterns and income inequality drive differences in energy demand between urban and rural regions. Heinonen et al. [32] introduces metropolitan, urban, semi-urban and rural contexts to document the relationship between urban form and carbon emissions in Finland. They claim that lifestyles are 'situated' as housing types, the availability of different goods, services and recreational activities, commuting distances and social contacts generate different behavioural patterns, time allocation and purchasing decisions, all of which resulting in different demands for energy.

Confirming geographically differentiated nature of low carbon transitions [24,25], Snape [33] notes the influence of built environment on solar photo voltaic (PV) uptake where the ratio of sun facing roof space to occupants is lower in urban environments than suburban and rural ones. Indeed, as of 2013 , only $36 \%$ of total domestic PV installations took place in cities in Great Britain [34]. Eshchanov et al. [35] highlight that residents of urban type multi-storey houses have relatively few opportunities for implementing renewable energy technologies (e.g. solar) due to the small surface area of their rooftops and also due to lack of sufficient surface area across their neighbourhoods. A number of studies emphasise the importance of peer effects on PV diffusion [11,13,36,37] The propensity to install PV panels increases with the number of previously installed systems in spatial proximity due to social interactions among the individuals. While limited evidence point to the diminishing nature of peer effects over time [13], it is not evident in the literature how the 
visibility of the panels influence the adoption decisions. This is mainly because the influence of built environment characteristics are represented by variables like housing [13] and population [12,36] density. It is clear that by influencing lifestyles and social practices (walking to a local school, train station versus driving to school, work), institutional and geographical contexts are likely to enhance or hinder the types and densities of social networks. Indeed, a growing number of studies across Europe confirm the presence of spatial regularities in PV adoption patterns $[12,25,38,39]^{5}$, abiding the first law of geography that 'everything is related to everything else, but near things are more related than distant things' [40, p.236].

This is not to say that the relationships between built environment characteristics, socio-economic factors and social interactions are linear, rather that our understanding of these interactions is rather limited. This study aims to provide empirical evidence for how energy attitudes and perceptions vary between large urban, small urban and rural areas that have been overlooked in the literature. Once this is established, further research will be needed to disentangle these relationships, which then can be used inform the design of effective and well-targeted policies consistent with Europe's energy policy goals. We use binary and ordered probit models to understand the impact of spatial factors while controlling for the other individual characteristics and time-invariant country fixed effects.

\section{Methods}

\subsection{Data}

\footnotetext{
5 In response to whether spatial spillover are driven by endogenous or exogenous neighbourhood effects, [12] claim that Manski (1993)'s contextual factors via the coordination or similarities in voluntary activities of local economic partnerships at regional scale might be in force.
} 
This study is based on a Eurobarometer survey of data across a number of policy areas, from energy technologies to employment, and social policy to services of general interest [41]. A total of 29,355 people were interviewed for the survey comprising residents of the European Union (EU) Member States, including the Turkish Cypriote Community and Candidate Country of Turkey.

The broad scope of this survey data has produced two other recent studies. The first investigates consumer satisfaction with household utilities for electricity, gas, telecommunications and internet [42] and the second, by Adelle and Withana [43], examines the differences in perception between EU and US publics towards climate change. To our knowledge, the present study is the first one to use this survey to investigate variation in energy attitudes and perceptions across self-determined categories of rural, small urban, and large urban areas.

\subsubsection{Key characteristics of dataset}

The survey data was collected using a multi-stage, random sampling design [44]. In the first stage, primary sampling units (PSU) were chosen from Eurostat's Nomenclature of Territorial Units for Statistics (NUTS2) or equivalent regions in every country. The selection of the PSU is done in a systematic way using a probability proportional to population size from sampling frames that were stratified by the degree of urbanization. In the second stage, a cluster of addresses is selected at random from each PSU sample. From these a sample was created systematically using standard random route procedures as every $N^{\text {th }}$ address from th initial address. Only one interview took place in each household, the respondent for which was drawn, at random, following the closest birthday rule. 
Due to missing information on a number of variables, a total of 15,559 interviews from 17 countries were included in the analysis. Approximately 1,000 individuals were surveyed in each country, except in Luxembourg and Northern Ireland where only 501 and 318 individuals were considered respectively. The distribution of the sample by the origin of respondents, both in terms of country and the type of geographical location, is presented in Error! Reference source not found.. Whilst we note that respondents' self-indicated designation of geographical settings may not truly represent the actual characteristics of their residential locations, comparison of urban areas in a cross-country context is rather difficult as definition of urban areas varies from one country to another $[45]^{6}$. However, the geographical context in the survey was captured consistently across the countries. The respondents were asked to make a choice out of three options (rural area or village; small or middle sized town and large town) in response to the question " Would you say you live in a ....?' It could also be argued that self-designation of geographical context is important on its own right as it reveals how individuals identify their environment.

\section{[insert Table 1]}

Table 1. Distribution of respondents by country of origin and location type

The Eurobarometer survey [41] contains a large number of questions. The full dataset includes 10 questions about the European Union (EU) and its neighbours; 14 questions on services of general interest; 22 questions on employment and social

\footnotetext{
6 To address this, the European Commission developed an urban-rural typology based on $1 \mathrm{~km} 2$ grid cells rather than the boundaries of administrative units. However, this typology uses different categories from the self-reported ones, making it difficult to compare the actual distribution of the population to the survey data. For details of the European typology, see: http://epp.eurostat.ec.europa.eu/statistics_explained/index.php/Urban-rural_typology\#Database.
} 
policy, 16 questions on energy technologies, and 15 questions on family planning. The survey also includes individual data on socio-economic and demographic variables such as age, family size, occupation, age when finished full-time education and home ownership.

Our interest is to understand how individuals' energy related perceptions and attitudes vary by different geographical settings. In particular, survey responses on the importance of energy related matters as a national issue, on energy policy priorities, conceptualisation of energy related issues, favoured energy fuels, and trusted sources of information on energy related matters have been analysed. Table 2 provides the questions and the distribution of the answers between the modalities for each. Energy related issues are recognised as a national issue by the majority of respondents. In this context, not surprisingly, on a scale to 7 , average importance of reducing energy use is 5.41. Hydro, ocean, wind and solar, on average, are most favoured energy sources.

[insert Table 2]

Table 2. Summary statistics on the explained variables

The econometric analysis of the data was based on a set of variables that controlled for differences across householder characteristics. Table 3 displays summary statistics, including the reference modality for each categorical variable. The explanatory variables include both individual characteristics, such as age, gender, occupation, etc., and behavioural variables, such as energy saving actions that we discuss next. Our main variable of interest was the self-perceived qualitative variable on the type of community the individuals live in. 
[insert Table 3]

Table 3. Summary statistics on the explanatory variables

\subsubsection{Creation of new explanatory variables from the survey data}

The survey includes data on the types of energy saving actions taken by the respondents. Cutting down on heating and lighting constitute more than half of all energy saving actions undertaken (Figure 2). Geographically, more than $70 \%$ of energy saving actions is undertaken in rural and small urban areas (35\% and 38\%, respectively). Maybe not surprisingly, large city residents make up $40 \%$ of householders who reported using more public transport. $39 \%$ of less car use is undertaken by small city residents. Rural households have undertaken most home insulations (at $43 \%$ ).

[insert Figure 2]

Figure 2. Distribution of energy saving actions by geographical areas

Novel to this study is the estimation of alternative models whereby these types of energy saving behaviours that the respondents have undertaken or not are included as explanatory "behavioural" variables. This approach allowed us to test the consistency between undertaking energy saving behaviours and holding certain views on energy related matters (Category 'Undertaking energy saving action' in Table 3). A total of nine different energy saving behaviours were provided as a binary choice so that the respondents could select any combination. These behaviours included actions from cutting down on heating/ air conditioning to using public transport more (see Table 4). Three actions focusing on car usage (using cars less, reducing driving speed or 
changing to a more efficient car) were aggregated to a single 'use car less' variable such that if a respondent selected one or more of these actions it would be included as 'yes' in the model.

\section{[insert Table 4]}

Table 4. Use of energy saving behaviours as explanatory variables

Finally, for question 6 (“And thinking about energy in 30 years, which do you think will be the three most used energy sources in (OUR COUNTRY)"), we combined individuals' perceptions on the most commonly used fuels today as a single behavioural variable (see "Perceptions on most used fuels" in Table 3). The types of fuels included in the survey were coal, oil, gas, nuclear, hydro, biomass, wind, solar, ocean energy. In the estimation, we grouped these fuel sources into three categories: fossil fuels (covering the first three fuels), nuclear and renewables (the last five fuels). We coded these explanatory variables as binary with a value of 1 if a particular type of energy (fossil, renewable or energy) was cited at least once. Respondents indicated fossil fuels as currently the most used fuel.

\subsection{Econometric model}

As presented in Table 2, the survey questions analysed were of two different types: a binary (yes/no; including Q1, Q3, Q4, one item in Q6) versus ordered choice (strength of preference on a scale, including Q2, Q5, two items in Q6 and Q7). We modeled the first category of variables using probit models and the second category of variables as ordered probit models. 


\section{Binary probit models}

We define the dependent variable as:

$$
\begin{array}{ll}
y_{i}=1 \quad \text { if } \quad y_{i}^{*}>0 \\
y_{i}=0 \text { if } \quad y_{i}^{*} \leq 0
\end{array}
$$

where $i$ is an individual respondent; $y_{i}^{*}$ is the latent variable measuring the intensity of accordance with each question and $y_{i}$ is the observed variable:

$$
y_{i}^{*}=x_{i}^{\prime} \beta+\varepsilon_{i}
$$

where $x_{i}$ is the vector of independent variables for respondent $i$ and $\varepsilon_{i}$ is a standard normally distributed error term. The regression parameters $\beta$ were estimated by maximum likelihood (ML) and their sign was interpreted as the positive or negative impact of the associated variable on the probability of answering yes to the question ${ }^{7}$.

\section{Ordered probit models}

For the ordered choice questions the dependent variable was defined as:

$$
y_{i}=j \quad \text { if } \quad \alpha_{j-1}<y_{i}^{*}<\alpha_{j} \quad j=1, \ldots m
$$

where $i$ is an individual respondent; $m$ is the number of alternatives in the response; $y_{i}^{*}$ is the latent variable measuring the intensity of accordance with each question; $y_{i}$ is the observed variable and $\alpha_{0}=-\infty, \alpha_{m}=\infty$. The ordered probit model is described as:

$$
y_{i}^{*}=x_{i}^{\prime} \beta+\varepsilon_{i}
$$

where $x_{i}$ is the vector of independent variables for respondent $i$ and $\varepsilon_{i}$ is a standard normally distributed error term. The regression parameter $\beta$ and the cut-off parameter $\alpha_{j}$ were estimated by ML. The sign of the coefficients was interpreted as the positive

\footnotetext{
${ }^{7}$ We also fitted logit models based on the assumption that the errors terms were distributed along a logistic distribution, but the results are qualitatively and quantitatively similar. Complete results are available from the authors upon request.
} 
or negative impact on the probability of answering a higher modality of the dependent variable.

\section{Specification of the models and econometric issues}

Using the explanatory variables, $x$, summarised in Tables 3 and 4, we estimated two different models for each survey question in Table 2. The model (1) was based on the socio-economic data collected in the survey. The model (2) incorporated data on undertaking energy saving action as further explanatory variables. Moreover, when analysing the perceptions on dominant fuels in the future, survey question 6 in Table 2, perceptions on today's most used fuels (fossil fuel, renewable or nuclear) are included as an additional explanatory variable. In all models, country fixed effects were added to control for time-invariant unobservable country characteristics. The estimated parameters associated to the country fixed effects are not included in the results due to difficulties with meaningful interpretation of these compound effects. Hence, they are excluded to save space but are available upon request.

Two further econometric issues worth mentioning. Firstly, although we are aware that our "behavioural" variables might be endogenous, we think that our specification to include a detailed list of individual characteristics and country-fixed effects will help mitigating this problem. Second, the main variable of interest, self-designated location variable, is subjective and largely dependent on the countries. To address this, we have estimated all models by interacting the self-designated location dummies with country-fixed effects. The results were not modified so we proceed without these interaction variables ${ }^{8}$. Finally, we used robust methods for statistical inference.

\footnotetext{
${ }^{8}$ More specifically, most of these interaction variables were not significant and when they were, they did not alter the marginal effect of the self-designated geographical dummies.
} 


\section{Results}

We estimated a mix of binary and ordered probit models the results of which are presented in five sub-sections: general perceptions on energy and environment, energy policy priorities, conceptualisation of energy related issues, perceptions on different sources of energy and trust to institutions for energy related information. In all the estimations, model (2) incorporates newly created behavioural variables as well as other socio-economic data on householder characteristics. The model (1) was estimated by using the latter category of variables.

\subsection{General perceptions on energy and environment}

Table 5 presents the estimation results for two questions on the identification of energy and environment as nationally important issues and importance of reducing energy use.

Respondents from small and large urban communities were less likely to identify energy-related issues of national importance compared to the respondents from rural areas. Even though belonging to a large urban community increased the probability of assigning a higher importance to reduce energy consumption, identification of environment as a national issue did not present any statistically significant variation by type of location. The relationship between undertaking of energy saving actions and the selection of environment and energy as important issues was statistically significant and positive.

It appears that women have a lower probability of identifying energy-related matters as important issues facing their country, in contrast to a higher probability of selecting environment-related issues. More educated people and people working in professional jobs or in services sector were more likely to select environment related issues while 
self-employed people and those who have internet, own a car or have paid/are paying for their house or apartment were more sensitive to energy related issues. Similarly, women, those with higher education, and employed professionals were more likely to assign higher importance to reducing energy consumption.

\section{[insert Table 5]}

Table 5. Energy related perceptions: ML binary and ordered probit estimation

\subsection{Perceptions on energy policy priorities}

The respondents were asked to identify two most important energy policy goals out of six propositions. A binary probit model is estimated for each proposition, which are presented in Table 6.

The selection of top energy policy priorities, regardless of whether energy saving actions are undertaken or not, vary by type of location. Householders in large cities were less likely to select guaranteeing low prices for consumers than those in rural and small urban areas. Instead, they were more likely to identify guaranteeing a continuous supply of energy and protecting the environment as energy policy priorities.

We noted significant gender differences where women had a lower probability to select propositions on guaranteeing continuous supply of energy, energy independence, reduction of energy consumption and competitiveness of industries than men. However, they had a higher probability to cite protecting the environment, which is consistent with the results of question 1. On the other hand, as age increased, which characterizes individuals who are also more likely to be home owners, guaranteeing continuous supply of energy and energy independence were more likely to be selected as policy priority areas. Guaranteeing low prices for consumers and 
protecting the environment seem to have a negative relationship with age. This highlights that as age increases, householders value continuity and independence of energy supply more than its price or protection of the environment. On the contrary, as years of education increased, protection of the environment was more likely to be selected as policy priority area while guaranteeing of low prices was less so. This indicates that as years of education increases protection of environment is perceived more important than price of energy. On the other hand, young families (with children $<10$ years old) prioritised low prices for consumers.

The respondents who had undertaken energy saving actions revealed different perceptions. The householders using car less or taking public transport more or saving energy at work, were more likely to identify protection of the environment as a policy goal while they were less likely to do so for guaranteeing low prices for consumers or continuous supply of energy. The householders who had insulated their homes were more likely to identify energy independence and economic competitiveness as energy policy priorities.

\section{[insert Table 6]}

Table 6. Energy policy priorities: ML probit estimation

\subsection{Conceptualisation of energy related issues}

The respondents were asked to express the first issue coming to their mind when thinking of energy related issues. The responses to this open ended question were presented in eleven categories in the survey, requiring a probit model for each choice as presented in Table 7.

Residents of small and large cities had a higher probability to mention nuclear energy, gas, energy consumption and environmental issues than those of rural areas. 
Moreover, residents of large cities revealed less often than those of rural areas that electricity supply and energy prices were an issue.

There were significant differences in framing of energy issues by gender. Female participants were less likely to conceptualise energy issues in terms of nuclear energy, types of fuels, energy dependency or renewable energy sources such as water, wind or sun. Instead electricity supply, energy consumption (i.e. saving/ wasting energy); ways to use energy such as heating, lighting and energy prices were the issues springing to their mind first. On the other hand, respondents who have undertaken energy efficiency actions were less likely to conceptualise energy in terms of electricity supply but instead more on saving/ wasting energy and renewable energies. The respondents undertaking personal and public transport actions were more likely to identify energy issues in terms of environmental issues like pollution or safety. The householders using more public transport were less likely to mention energy prices as the first issue coming to their minds.

[insert Table 7]

Table 7. Conceptualisation of energy system: ML probit estimation

\subsection{Perceptions on different sources of energy}

Householders' perceptions on different sources of energy were asked in question 5. For each energy source (coal, oil, gas, nuclear, hydroelectric, biomass, wind, solar, ocean), we estimated ordered probit model to analyse the factors affecting the respondents' preferences from a scale of 1 (strongly opposed) to 7 (strongly in favour) in Table 8.

[insert Table 8] 
Interesting differences were noted between residents of rural and urban areas. We found that people in large urban areas were less in favour of coal, biomass, wind and ocean while they were more fond of gas and nuclear. Small city residents were also more likely to favour gas than those in rural areas. This might be due to urban residents' familiarity with such large, centralised systems and a lack of knowledge on alternatives to traditional energy sources.

Women were more in favour of coal, oil, wind than men while they appeared less in favour of gas, nuclear, hydroelectric, biomass and ocean energy. We found older people were more in favour of traditional sources of energy, including oil, gas, nuclear and biomass. Consequently, they were less in favour of wind, which is relatively newer energy source. For the other variables, we noted that owning a computer and internet had a strong negative effect on the opinion pertaining to coal, oil and gas and a positive effect on solar and ocean, probably indicating the role of internet connection on householder's access to information on these non-conventional energy sources. The householders who use their car less or more public transport are in favour of biomass, wind and solar energy. But having insulation house has a negative effect on wind but positive effect on biomass.

In Question 6, we investigated the perceptions of the respondents on energy sources that would be most used in 30 years. Fossil fuels and renewables were modelled in ordered probit form where the dependent variable was the number of times the respondent had selected any energy source from their corresponding group. Nuclear energy was modelled as a binary probit model. In each model, a new variable 
capturing the respondents' choice of energy source most used today was included to control for the effects of perceptions on the current situation (Table 9).

\section{[insert Table 9]}

Table 9. Perceptions on dominant fuel sources in the future: ML probit and ordered probit estimation

It appears that residents in small and large urban areas have a higher probability to cite fossils and nuclear as being important for the future and a lower probability to cite renewable sources compared to rural counterparts. This result is consistent with our previous finding on urban residents' overlooking potential contributions renewables can play in future energy system.

Gender effects were important again with women citing renewable energies more often than men while they had a lower probability of mentioning fossil and nuclear energies as important in the next 30 years. This pattern was reversed for older people as age increases they were more likely to envision nuclear to be part of the future energy mix while less so with the renewables. The householders who have insulated their homes or use their car less are more likely perceive renewables to be a dominant fuel source in the future. We also noted that the respondents, who don't think renewables are important today but fossil fuels are, were more likely to think fossils fuels to be used most in the future. In contrast, the respondents thinking fossil fuels and nuclear are most used fuels today were more likely to think that nuclear would be most used fuel in the future. Finally, the probability of citing renewable energy as important in the future increased when the respondent had cited fossils, renewable and nuclear as being important today. It seems future importance of renewables in future energy mix depends on whether they are perceived to contribute to today's energy supply. The perceptions therefore seem to be asymmetric. 


\subsection{Trust to different institutions for energy related information}

Finally, we analysed the respondents' trust to different institutions for information about energy related matters (question 8). We estimated ordered probit models for each source of information where the dependent variable goes from 1 (trust totally) to 4 (Not at all) (Error! Reference source not found.). The survey includes a variety of institutions from European level to national ones: national government; regional/ local government; the European Union (EU); electricity, gas and other energy companies; scientists; environmental protection organisations or consumer associations; journalists and political parties.

[insert Table 10]

Table 10. Trust to institutions on energy matters: ML ordered probit estimation

We found a clear cleavage between urban and rural residents. Both large and small city residents seem to trust more the EU, the scientists, not-for-profit organisations, and the journalists than rural ones. Furthermore, large urban residents trusted national government and political parties more than rural counterparts. This could be due to physical and social proximity of large city residents to the centres of knowledge and power.

Women were more likely to trust energy companies and environmental protection agencies than men while they were less likely to have confidence in scientists and the EU. A positive relationship has been detected between increases in years of education and expression of trust in all institutions. Employed professionals who are likely to have university degrees expressed trust in all institutions but the utilities. People 
having access to the internet seem to trust the EU, the scientists and not-for-profit organisations more as a source of information but tend to distrust utilities. In contrast, the homeowners (who have paid or still paying off their mortgages) were more likely to trust the national and sub-national government, the EU and the utilities.

\section{Discussion}

Some of our findings on the importance of demographic and socio-economic factors confirm the past research while our findings on spatial factors, consistency of energy perceptions and behaviours and trust in the source of information offer new insights to the existing knowledge which are discussed in subsections below.

\subsection{Demographic and socio-economic factors}

Our analysis reiterates the influence of some of the socio-economic factors on energy related perceptions and behaviours. On perceptions related to energy and environment we find that as age increases householders are more likely to recognise the importance of reducing energy. Yet, protecting the environment is less likely to be seen as an energy policy priority. Even though these statements seem to be at odds with each other, it can be explained by Mills and Schleich's [17] finding that older age groups are more motivated by financial savings than environmental reasons in undertaking energy efficiency activities. Yet, guaranteeing low prices for consumers is less likely to be seen as an energy policy priority by the older age groups. Instead, as age increases householders would like to be assured of continuous supply and independence of energy. As the respondents were asked to make a trade-off by selecting only two energy policy priorities, it seems as if elderly value continuity of energy supply more highly than lower prices. Similarly, years of education positively 
affects both the recognition of environment as a national issue and importance of reducing energy, leading to the identification of protecting the environment as an energy policy priority area, in line with other studies [17]. We find young families prioritise low prices for consumers. More educated individuals are less likely to perceive guaranteeing low energy prices for consumers as an energy policy priority area.

We further find strong gender effects where women are less likely to identify energy as a national important issue. Not only do they perceive environment as a national important issue but also protecting the environment as an energy policy priority area. These findings seem to support the literature on women being more concerned about climate change than men [46-48]. Our study contrasts earlier studies claiming women care more about energy security [49] as we find being female is negatively correlated with guaranteeing continuous supply or independence of energy. Surprisingly though women are in less favour of the use of gas, nuclear, hydroelectricity, biomass and ocean in their country than men. They are instead more in favour of some fossil fuels (coal, oil) and wind. Yet, in the future they are more likely to think of renewables as most dominant source of fuel than men. As age increases, traditional fuel sources like oil, gas, nuclear and biomass are more favoured which are expected to be replaced by nuclear in the future. The statistically significant negative relationship between age and renewables being the most used fuel in the next 30 years indicates that elderly are less likely to envision a renewables-dominated energy future.

\subsection{Spatial factors}

Our analysis reveals that urban householders are less likely to recognise energy as of national importance than rural householders, which might be linked to the presence of 
other more depressing policy issues such as income inequalities in urban life. Maybe as a result of the interdependencies of many aspects of urban life to energy, large urban householders would like to see guaranteeing a continuous supply of energy and protecting the environment, at the expense of low prices, as energy policy priorities than rural ones. On the other hand, large city residents are more likely to recognise importance of reducing energy than rural households while small city residents don't present a statistically significant relationship.

We find statistically significant and consistent differences on how energy issues are conceptualised by householders living in urban and rural areas. When thinking of energy issues, nuclear energy, gas, energy consumption (including saving, wasting energy) and environmental issues (such as pollution or safety) are mentioned by large and small city residents more often than their rural counterparts. Compared to rural households, large city residents are less likely to think of energy issues in terms of energy prices, which is consistent with their disagreeing to guaranteeing low prices for consumers as energy policy priority area. Large urban households are less likely to mention electricity supply than rural ones, maybe due to limited opportunities for renewable energy applications in urban settings [35]. Policies tuned at energy consumption or centralised energy systems like gas or nuclear energy might be more receptive for urban householders. The large city residents are in less favour of a variety of fossil (coal) and alternative (biomass, wind and ocean) fuels than rural counterparts, contradicting Halder et al.'s [50] finding on positive perceptions to bioenergy by young urban citizens. Yet, small city residents are more in favour of wind energy than rural ones. On the other hand, both large and small city residents are more in favour of centralised gas systems than the rural ones. Looking to the future, both large and small city residents are less likely to think of a renewables-dominated 
energy future. Instead, both groups think more often than rural residents that nuclear and fossil fuels will be dominant fuels in the future. These relationships contradict with large city residents' preference to protect the environment as policy priority. While indeed this could be due to limited opportunities for renewable energy applications in urban areas [35], it conflicts with expected higher consumer engagement as envisioned in a smart grid where consumers actively change their demands in response to intermittent energy supply. In the UK for example, electrification of heat and transport are recognised as part of a future low carbon energy system [51]. Yet, the lack of recognition of roles renewables can play in meeting future energy demands might undermine consumers' willingness to take part in demand side programmes. These issues might be more crucial in densely populated city centres where there could be network constraints to put more wires in the ground or build new substations to meet higher demands for electricity.

\subsection{Energy behaviours and perceptions}

We found differences in the relationships between types of energy efficiency actions and energy related matters. Overall, undertaking energy efficiency actions are positively linked with the recognition of energy and environment as nationally important issues. Yet, types of energy saving behaviour seem to drive different energy policy priorities. We detected positive links between the changes in transport habits and selection of the protection of the environment and reducing energy consumption as a policy goal. However, these transport-cautious householders were less likely to prioritise guaranteeing low prices for consumers and continuous supply of energy as policy goals. The former can be linked to inelastic transport demand for gasoline [52] and an anticipation that prices will not go down. Yet, it is interesting that continuous 
supply is not selected as an energy policy priority. They further conceptualise energy in terms of energy consumption, renewable energies and environmental issues. On the other hand, the householders who have insulated their house would like to see ensuring the independence in the field of energy and economic competitiveness as energy policy priorities. The householders who have undertaken energy efficiency actions are in general less favour of oil and gas but more of renewable resources like biomass, wind, solar and ocean energy.

These findings seem to suggest a behaviour not predicated on expectations of lower energy prices but rather a motivation to do something about energy and environment. This value and action consistency seems to support the theory of planned behaviour [22] and possibly be linked to self-efficacy for energy and environment (the belief that they have done enough in their power to address those issues) [53]. Moreover, the positive links between the changes in transport habits and protection of the environment as a policy goal but not so with home insulation raise whether behavioural spillovers [spread of a new behaviour to other associated behaviours, 54] depend on the type of action undertaken. Using car less or more of public transport are types of activities people undertake continuously whereas insulation of home is a one-off decision. While the data does not help to identify the nature of the spillover effect (whether more aware householders are likely to undertake energy efficiency actions or vice versa), targeting these householders for the adoption of novel low carbon technologies via policy incentives can help with their diffusion.

The perceptions on today's most used fuels seem to drive what fuels are perceived to be dominant in the future. The householders who think renewables is today's most used fuel are more likely to perceive renewables be dominant in the future while less so of fossil fuels. The householders who think fossil fuels are today's most used 
energy source are the only group who perceive them to be dominant in the future. Both groups, perceiving fossil fuels and nuclear as today's dominant energy source, envision renewables making significant contributions in the future.

\subsection{Trust in the source of information}

Our study analyses the perceived trust in different institutions for the provision of energy related information. Previous studies report lack of trust towards energy companies in national [55,56] or international [57] contexts. Mumford and Gray [58] frame trust in terms of social tensions between energy companies, regulators and governments, non-governmental organisations and consumers. Contrary to the findings in the literature, we find that having higher years of education, being female and home-owner contribute positively towards trust in energy companies as source of information about energy related issues while undertaking energy saving actions and access to internet undermine this trust. Indeed, this study does not confirm Craig's [21] analysis where awareness of energy efficiency actions are linked with more positive views of utility companies. We didn't detect any geographical differences on trust to energy companies. However, both small and large city residents express more trust to the EU, environmental protection agencies and journalists than rural ones. Undertaking energy efficiency facilitates trust to the EU, scientists and environmental protection agencies.

\section{Conclusions}

Current research into understanding of energy attitudes and perceptions neglects the location of householders and any potential roles geography might play. An exception to this is cities where a growing body of literature focuses on the governance of urban energy systems. Yet, the pace of changes required in transition to a low carbon 
economy can only be achieved via understanding of differences in conceptualisation of energy issues beyond urban areas. These issues warrant scrutiny especially for two reasons. First, looking to the future, given the geographically divergent nature of low carbon transitions [24], understanding these differences can help with finding ways to utilise these differences instead of creating further inequalities. This then in turn can help with the design of more effective and well targeted policies.

Following a conceptual framework, we empirically tested the nature and scope of differences in attitudes and perceptions across rural, small urban and large urban areas. Using a representative Eurobarometer survey data, we disclose how social conceptions of important energy issues, Europe's future energy priorities and future energy system characteristics are influenced by energy saving behaviours as well as other socio-economic variables. Our analysis reveals that beyond demographic and socio-economic differences, there are significant differences in people's perceptions and attitudes across different geographical contexts. Large city residents are more likely to identify guaranteeing a continuous supply of energy and protecting the environment while less so of ensuring low prices for consumers as energy policy priorities than rural inhabitants. Thinking of energy issues, nuclear energy, gas, energy consumption (saving or wasting energy) and environmental issues come to both large and small city residents' minds more often than those of rural ones.

Compared to rural residents, inhabitants of large cities are less in favour of coal, biomass, wind and ocean energy. Only renewable energy source favoured by small city residents is wind energy. As a result, maybe not surprisingly, both large and small city residents are less likely to envision renewables to be a dominant energy source in the future. Groups of both urban inhabitants trust European Union, environmental protection agencies and journalists for energy related information more than the rural 
counterparts. Yet, large city residents rely on national governments and political parties as well. In line with the literature, our study confirms distrust towards utilities. Our research highlights several issues that are relevant for policy makers:

- On socio-economic factors, consistent with past research we find that women are more concerned about environment than men. We are hesitant to state firmly that women have a more functional attitude towards energy by focusing on what it enables them to do. Yet, given the large sample size, we find statistically significant evidence that they do not think of energy issues in terms of renewable resources or electricity supply, but rather around what energy is used for and its price. This may mean that messages on how different policies can enable women to carry out their daily activities might be more effective than those focusing on costs.

- Given an ample literature on the acceptance of small scale renewable energy installations, where these installations are located are not studied to the same extent. Lack of space to install these technologies in urban areas [35] and consequently their unfamiliarity [14] can be contributing factors for urban residents' overlooking the potential contributions renewables can make to a low carbon energy system. In the face of ever increasing demand for energy, the efforts to engage urban residents in demand side programs in a smarter grid to deal with intermittency of renewables and network constraints in the grid can be undermined. The promotion of community energy schemes such as photovoltaics in urban areas can help with increasing the familiarity of urban residents with renewable energy options.

- Our study provides further evidence on distrust towards utilities in an international context. Given the pace of changes needed in the ways energy 
generated and delivered, finding meaningful ways to engage with the public is paramount for energy industry.

- On energy policy priorities, continuity of the energy supply and energy independence seem to resonate more with the public than price of energy. Hence, rather than the costs and cost-effectiveness of different policies, they might be framed in terms of these aspects.

Our research does not go as far as uncovering social processes and mechanisms and built environment characteristics underpinning these spatial differences. In particular, there is a need to go beyond density measures to unpack the influence of built environment characteristics on energy transitions. The measures such as the distances between houses (detached or terraced), the sizes of gardens, land use mix, percentage of green space [59] can provide novel insights. How these influence the nature and type of social interactions among the householders emerges as another line of enquiry. These non-linear interactions between built environment characteristics, socioeconomic factors and social interactions highlight the need for more multidisciplinary research to assess economic-environmental processes and outcomes in terms of how 'just', 'natural' or 'good' they are [60]. Despite opportunities presented by smart grids in enabling a cost-effective transition to a low carbon economy [61], the implementation of their capabilities is expected to be geographically uneven [55]. Understanding of differences in social construction of smart grids [62] in different geographical contexts will provide invaluable insights for academia, policy makers and energy industry in progressing towards a smart energy transition that is 'just'. 


\section{Acknowledgements}

We acknowledge the research assistance and support by our intern, Iris Namark of Boston University.

\section{References}

[1] IEA. World Energy Outlook. Paris: 2013.

[2] WEC. Time to get real - the case for sustainable energy investment. 2013.

[3] Shove E. Beyond the ABC: climate change policy and theories of social change. Environ Plan A 2010;42:1273-85. doi:10.1068/a42282.

[4] Whitmarsh L, O’Neill S, Lorenzoni I. Climate change or social change? Debate within, amongst, and beyond disciplines. Environ Plan A 2011;43:258-61. doi:10.1068/a43359.

[5] Shove E. On the difference between chalk and cheese- - a response to Whitmarsh et al's comments on "Beyond the ABC: climate change policy and theories of social change." Environ Plan A 2011;43:262-4. doi: $10.1068 / \mathrm{a} 43484$.

[6] Giddens A. The Constitution of Society. Cambridge: Polity Press; 1984.

[7] Owens S, Driffill L. How to change attitudes and behaviours in the context of energy. Energy Policy 2008;36:4412-8. doi:10.1016/j.enpol.2008.09.031.

[8] Shammin MR, Herendeen RA, Hanson MJ, Wilson EJH. A multivariate analysis of the energy intensity of sprawl versus compact living in the U.S. for 2003. Ecol Econ 2010;69:2363-73. doi:10.1016/j.ecolecon.2010.07.003.

[9] Nichols BG, Kockelman KM. Life-cycle energy implications of different residential settings: Recognizing buildings, travel, and public infrastructure. Energy Policy 2014;68:232-42. doi:10.1016/j.enpol.2013.12.062.

[10] Hori S, Kondo K, Nogata D, Ben H. The determinants of household energysaving behavior: Survey and comparison in five major Asian cities. Energy Policy 2013;52:354-62. doi:10.1016/j.enpol.2012.09.043.

[11] Rode J, Weber A. Does Localized Imitation Drive Technology Adoption? A Case Study on Solar Cells in Germany. 2013.

[12] Balta-Ozkan N, Yildirim J, Connor PM. Regional distribution of photovoltaic deployment in the UK and its determinants: A spatial econometric approach. Energy Econ 2015;51:417-29. doi:10.1016/j.eneco.2015.08.003.

[13] Graziano M, Gillingham K. Spatial patterns of solar photovoltaic system adoption: The influence of neighbors and the built environment. J Econ Geogr 2015;15:815-39. doi:10.1093/jeg/lbu036.

[14] Karytsas S, Theodoropoulou H. Socioeconomic and demographic factors that 
influence publics' awareness on the different forms of renewable energy sources. Renew Energy 2014;71:480-5. doi:10.1016/j.renene.2014.05.059.

[15] Sardianou E, Genoudi P. Which factors affect the willingness of consumers to adopt renewable energies? Renew Energy 2013;57:1-4.

doi:10.1016/j.renene.2013.01.031.

[16] Schleich J, Mills B, Dütschke E. A brighter future? Quantifying the rebound effect in energy efficient lighting. Energy Policy 2014;72:35-42.

[17] Mills B, Schleich J. Residential energy-efficient technology adoption, energy conservation, knowledge, and attitudes: An analysis of European countries. Energy Policy 2012;49:616-28. doi:10.1016/j.enpol.2012.07.008.

[18] Sovacool BK. What are we doing here? Analyzing fifteen years of energy scholarship and proposing a social science research agenda. Energy Res Soc Sci 2014;1:1-29. doi:10.1016/j.erss.2014.02.003.

[19] Steg L. Promoting household energy conservation. Energy Policy 2008;36:4449-53. doi:10.1016/j.enpol.2008.09.027.

[20] Bolderdijk JW, Gorsira M, Keizer K, Steg L. Values determine the (in)effectiveness of informational interventions in promoting proenvironmental behavior. PLoS One 2013;8:e83911. doi:10.1371/journal.pone.0083911.

[21] Craig CA. Energy consumption, energy efficiency, and consumer perceptions: A case study for the Southeast United States. Appl Energy 2016;165:660-9. doi:10.1016/j.apenergy.2015.12.069.

[22] Ajzen I. The theory of planned behavior. Organ Behav Hum Decis Process 1991;50:179. doi:10.4135/9781446249215.n22.

[23] Testa F, Cosic a., Iraldo F. Determining factors of curtailment and purchasing energy related behaviours. J Clean Prod 2015:1-10. doi:10.1016/j.jclepro.2015.07.134.

[24] Bridge G, Bouzarovski S, Bradshaw M, Eyre N. Geographies of energy transition: Space, place and the low-carbon economy. Energy Policy 2013;53:331-40. doi:10.1016/j.enpol.2012.10.066.

[25] Balta-Ozkan N, Watson T, Mocca E. Spatially uneven development and low carbon transitions:Insights from urban and regional planning. Energy Policy 2015;85:500-10. doi:10.1016/j.enpol.2015.05.013.

[26] Bulkeley H, Broto VC, Hodson M, Marvin S. Cities and Low Carbon Transitions. Taylor \& Francis; 2010. doi:10.4324/9780203839249.

[27] Lopes M a. R, Antunes CH, Martins N. Energy behaviours as promoters of energy efficiency: A 21st century review. Renew Sustain Energy Rev 2012;16:4095-104. doi:10.1016/j.rser.2012.03.034.

[28] Sardianou E. Estimating energy conservation patterns of Greek households. Energy Policy 2007;35:3778-91. doi:10.1016/j.enpol.2007.01.020.

[29] Urban J, Scasny M. Exploring domestic energy-saving: The role of environmental concern and background variables. Energy Policy 2012;47:69- 
80.

[30] Druckman A, Jackson T. Household energy consumption in the UK: A highly geographically and socio-economically disaggregated model. Energy Policy 2008;36:3177-92. doi:10.1016/j.enpol.2008.03.021.

[31] Wiedenhofer D, Lenzen M, Steinberger JK. Energy requirements of consumption: Urban form, climatic and socio-economic factors, rebounds and their policy implications. Energy Policy 2013;63:696-707. doi:10.1016/j.enpol.2013.07.035.

[32] Heinonen J, Jalas M, Juntunen JK, Ala-Mantila S, Junnila S. Situated lifestyles: I. How lifestyles change along with the level of urbanization and what the greenhouse gas implications are - a study of Finland. Environ Res Lett 2013;8:025003. doi:10.1088/1748-9326/8/2/025003.

[33] Snape JR. Smart grids , local adoption of distributed generation and the feed in tariff policy incentive 2013:93-9.

[34] Balta-Ozkan N, Watson T, Connor PM, Axon C. The UK's transition to a smarter energy system: contextualising spatial differences and their implications. Florida, U.S.A.: 2014.

[35] Eshchanov BR, Grinwis Plaat Stultjes M, Eshchanov R a., Salaev SK. Prospects of renewable energy penetration in Uzbekistan-Perception of the Khorezmian people. Renew Sustain Energy Rev 2013;21:789-97. doi:10.1016/j.rser.2013.01.023.

[36] Müller S, Rode J. The adoption of photovoltaic systems in Wiesbaden, Germany. Econ Innov New Technol 2013;22:519-35. doi:10.1080/10438599.2013.804333.

[37] Bollinger B, Gillingham K. Peer Effects in the Diffusion of Solar Photovoltaic Panels. Mark Sci 2012;31:900-12. doi:10.1287/mksc.1120.0727.

[38] Hofierka J, Kaňuk J, Gallay M. The Spatial Distribution of Photovoltaic Power Plants in Relation to Solar Resource Potential: The Case of the Czech Republic and Slovakia. Morav Geogr Reports 2014;22:26-33.

[39] Schaffer AJ, Brun S. Beyond the sun - Socioeconomic drivers of the adoption of small-scale photovoltaic installations in Germany. Energy Res Soc Sci 2015;10:220-7. doi:10.1016/j.erss.2015.06.010.

[40] Tobler WR. A computer movie simulating urban growth in the Detroit region. Econ Geogr 1970;46:234-40.

[41] EC. Eurobarometer 65.3: Neighbours of the European Union, Services of General Interest, Employment and Social Policy, Energy Technologies, and Family Planning May-June 2006. 2007.

[42] Clifton J, Díaz-Fuentes D, Fernández-Gutiérrez M. The impact of socioeconomic background on satisfaction: Evidence for policy-makers. J Regul Econ 2014;46:183-206. doi:10.1007/s11149-014-9251-1.

[43] Adelle C, Withana S. Public perceptions of climate change and energy issues in the EU and the United States. In: Oberthur S, Pallemaerts M, editors. New Clim. Policies Eur. Union Intern. Legis. Clim. Dipl., Brussels: Brussels 
University Press; 2010, p. 309-36. doi:10.1163/_q3_SIM_00374.

[44] GESIS. Eurobarometer 65.3 - Variable Report. 2012. doi:10.4232/1.10975.

[45] OECD. Redefining “Urban " - A new way to measure metropolitan areas. 2012. doi:http://dx.doi.org/10.1787/9789264174108-en.

[46] Safi AS, Smith WJ, Liu Z. Rural Nevada and climate change: vulnerability, beliefs, and risk perception. Risk Anal 2012;32:1041-59. doi:10.1111/j.15396924.2012.01836.x.

[47] McCright AM. The effects of gender on climate change knowledge and concern in the American public. Popul Environ 2010;32:66-87. doi:10.1007/s11111-010-0113-1.

[48] Arabatzis G, Malesios C. Pro-environmental attitudes of users and non-users of fuelwood in a rural area of Greece. Renew Sustain Energy Rev 2013;22:62130. doi:10.1016/j.rser.2013.02.026.

[49] Knox-Hayes J, Brown MA, Sovacool BK, Wang Y. Understanding Attitudes toward Energy Security: Results of a Cross-National Survey. Glob Environ Chang 2013;23:609-22.

[50] Halder P, Pietarinen J, Havu-Nuutinen S, Pelkonen P. Young citizens' knowledge and perceptions of bioenergy and future policy implications. Energy Policy 2010;38:3058-66. doi:10.1016/j.enpol.2010.01.046.

[51] DECC. The Carbon Plan: Delivering our low carbon future. 2011.

[52] Arzaghi M, Squalli J. How price inelastic is demand for gasoline in fuelsubsidizing economies? Energy Econ 2015;50:117-24. doi:10.1016/j.eneco.2015.04.009.

[53] Mah DN, van der Vleuten JM, Hills P, Tao J. Consumer perceptions of smart grid development: Results of a Hong Kong survey and policy implications. Energy Policy 2012;49:204-16. doi:10.1016/j.enpol.2012.05.055.

[54] Poortinga W, Whitmarsh L, Suffolk C. The introduction of a single-use carrier bag charge in Wales: Attitude change and behavioural spillover effects. J Environ Psychol 2013;36:240-7. doi:10.1016/j.jenvp.2013.09.001.

[55] Balta-Ozkan N, Watson T, Connor P, Axon C, Whitmarsh L, Davidson R, et al. Scenarios for the Development of Smart Grids in the UK Synthesis Report Scenarios for the Development of Smart Grids in the UK Synthesis Report. London: 2014.

[56] Goulden M, Bedwell B, Rennick-Egglestone S, Rodden T, Spence A. Smart grids, smart users? The role of the user in demand side management. Energy Res Soc Sci 2014;2:21-9. doi:10.1016/j.erss.2014.04.008.

[57] Balta-Ozkan N, Amerighi O, Boteler B. A comparison of consumer perceptions towards smart homes in the UK, Germany and Italy: reflections for policy and future research. Technol Anal Strateg Manag 2014;26:1176-95. doi:10.1080/09537325.2014.975788.

[58] Mumford J, Gray D. Consumer engagement in alternative energy-Can the regulators and suppliers be trusted? Energy Policy 2010;38:2664-71. 
doi:10.1016/j.enpol.2009.05.054.

[59] Bramley G, Dempsey N, Power S, Brown C, Watkins D. Social sustainability and urban form: evidence from five British cities. Environ Plan A 2009;41:2125-42. doi:10.1068/a4184.

[60] Editorial. Emerging Themes in Economic Geography: Outcomes of the Economic Geography 2010 Workshop. Econ Geogr 2011;87:111-26. doi:10.1111/j.1944-8287.2011.01114.x.

[61] Faruqui A, Harris D, Hledik R. Unlocking the $€ 53$ billion savings from smart meters in the EU: How increasing the adoption of dynamic tariffs could make or break the EU's smart grid investment. Energy Policy 2010;38:6222-31. doi:10.1016/j.enpol.2010.06.010.

[62] Wolsink M. The research agenda on social acceptance of distributed generation in smart grids: Renewable as common pool resources. Renew Sustain Energy Rev 2012;16:822-35. doi:10.1016/j.rser.2011.09.006.

[63] IEA-RETD. Residential prosumers - drivers and policy options (re-prosumers). 2014.

[64] Manski CF. Identification of Endogenous Social Effects : The Reflection Problem. Rev Econ Stud 1993;60:531-42. 
Table 1.

Distribution of respondents by country of origin and location type.

\begin{tabular}{|c|c|c|c|c|c|}
\hline \multirow[b]{2}{*}{ Country } & \multirow{2}{*}{$\begin{array}{l}\text { Number } \\
\text { of people } \\
\text { surveyed }\end{array}$} & \multirow{2}{*}{$\begin{array}{l}\text { Share in } \\
\text { survey (in } \\
\% \text { ) }\end{array}$} & \multicolumn{3}{|c|}{$\begin{array}{c}\text { Distribution of respondents by location type } \\
\text { within each country }(\%)\end{array}$} \\
\hline & & & Rural areas & $\begin{array}{l}\text { Small urban } \\
\text { areas }\end{array}$ & $\begin{array}{l}\text { Large urban } \\
\quad \text { areas }\end{array}$ \\
\hline Austria & 1011 & 6.50 & 37 & 28 & 35 \\
\hline Belgium & 1057 & 6.79 & 51 & 34 & 15 \\
\hline Denmark & 1021 & 6.56 & 27 & 40 & 33 \\
\hline East Germany & 501 & 3.22 & 28 & 41 & 31 \\
\hline Finland & 1013 & 6.51 & 31 & 48 & 21 \\
\hline France & 1034 & 6.65 & 37 & 53 & 11 \\
\hline Great-Britain & 1019 & 6.55 & 27 & 40 & 33 \\
\hline Greece & 1000 & 6.43 & 30 & 18 & 51 \\
\hline Ireland & 1000 & 6.43 & 42 & 38 & 20 \\
\hline Italy & 1024 & 6.58 & 18 & 64 & 19 \\
\hline Luxembourg & 501 & 3.22 & 42 & 38 & 20 \\
\hline Netherlands & 1020 & 6.56 & 41 & 35 & 23 \\
\hline Northern Ireland & 318 & 2.04 & 36 & 30 & 34 \\
\hline Portugal & 1000 & 6.43 & 47 & 31 & 22 \\
\hline Spain & 1006 & 6.47 & 46 & 31 & 23 \\
\hline Sweden & 1006 & 6.46 & 45 & 33 & 22 \\
\hline West-Germany & 1028 & 6.61 & 26 & 47 & 27 \\
\hline
\end{tabular}


Table 2.

Summary statistics on the explained variables.

\begin{tabular}{|c|c|c|c|c|c|c|c|c|c|}
\hline Question 1 & $\begin{array}{l}\text { What are the most important } \\
\text { issues facing (OUR } \\
\text { COUNTRY) today? }\end{array}$ & No & Yes & & & & & & \\
\hline & Energy related issues & 0.855 & 0.145 & & & & & & \\
\hline & Protecting the environment & 0.864 & 0.136 & & & & & & \\
\hline \multirow[t]{2}{*}{ Question 2} & $\begin{array}{l}\text { Using a scale from } 1 \text { to } 7 \text {, how } \\
\text { important do you think it is to } \\
\text { reduce energy consumption in } \\
\text { (OUR COUNTRY)?* }\end{array}$ & $\begin{array}{c}\text { 0 } \\
\text { Don't } \\
\text { know }\end{array}$ & $\begin{array}{l}1 \text { Not } \\
\text { import. }\end{array}$ & 2 & 3 & 4 & 5 & 6 & $\begin{array}{l}7 \text { Ext. } \\
\text { import. }\end{array}$ \\
\hline & $\begin{array}{c}\text { Importance of reducing } \\
\text { energy }\end{array}$ & 0.025 & 0.008 & 0.013 & 0.044 & 0.124 & 0.258 & 0.238 & 0.290 \\
\hline \multirow[t]{7}{*}{ Question 3} & $\begin{array}{l}\text { In your opinion, which two of } \\
\text { the following should be given } \\
\text { top priority in the } \\
\text { (NATIONALITY) } \\
\text { Government's energy policy? }\end{array}$ & No & Yes & & & & & & \\
\hline & $\begin{array}{l}\text { Guaranteeing low prices for } \\
\text { consumers }\end{array}$ & 0.589 & 0.411 & & & & & & \\
\hline & $\begin{array}{l}\text { Guaranteeing a continuous } \\
\text { supply of energy }\end{array}$ & 0.63 & 0.37 & & & & & & \\
\hline & $\begin{array}{l}\text { Guaranteeing independence in } \\
\text { the field of energy }\end{array}$ & 0.819 & 0.181 & & & & & & \\
\hline & Protecting the environment & 0.698 & 0.302 & & & & & & \\
\hline & $\begin{array}{l}\text { Guaranteeing the } \\
\text { competitiveness of our } \\
\text { industries }\end{array}$ & 0.915 & 0.085 & & & & & & \\
\hline & Reduce energy consumption & 0.846 & 0.154 & & & & & & \\
\hline \multirow[t]{12}{*}{ Question 4} & $\begin{array}{l}\text { When you think about energy } \\
\text { related issues, what comes } \\
\text { first into your mind? } \\
\text { (WRITE DOWN ALL } \\
\text { SPONTANEOUS } \\
\text { ANSWERS) } \\
\end{array}$ & No & Yes & & & & & & \\
\hline & Nuclear energy & 0.911 & 0.089 & & & & & & \\
\hline & Electricity supply & 0.861 & 0.139 & & & & & & \\
\hline & Fuel & 0.915 & 0.085 & & & & & & \\
\hline & Gas & 0.955 & 0.045 & & & & & & \\
\hline & Renewable energies & 0.841 & 0.159 & & & & & & \\
\hline & Energy consumption & 0.948 & 0.052 & & & & & & \\
\hline & Ways to use energy & 0.959 & 0.041 & & & & & & \\
\hline & Importance of energy & 0.971 & 0.029 & & & & & & \\
\hline & Energy dependency & 0.977 & 0.023 & & & & & & \\
\hline & Environmental issues & 0.93 & 0.07 & & & & & & \\
\hline & Energy prices & 0.734 & 0.266 & & & & & & \\
\hline \multirow[t]{10}{*}{ Question 5} & $\begin{array}{c}\text { Are you in favour or opposed } \\
\text { to the use of these different } \\
\text { sources of energy in (OUR } \\
\text { COUNTRY)** }\end{array}$ & $\begin{array}{c}0 \\
\text { Don't } \\
\text { know }\end{array}$ & $\begin{array}{l}1 \\
\text { Strong } \\
\text { oppose }\end{array}$ & 2 & 3 & 4 & 5 & 6 & $\begin{array}{l}7 \\
\text { Strong } \\
\text { favour }\end{array}$ \\
\hline & Coal & 0.049 & 0.134 & 0.125 & 0.156 & 0.183 & 0.147 & 0.096 & 0.110 \\
\hline & Oil & 0.031 & 0.073 & 0.089 & 0.143 & 0.206 & 0.188 & 0.126 & 0.144 \\
\hline & Gas & 0.036 & 0.034 & 0.043 & 0.087 & 0.166 & 0.213 & 0.186 & 0.234 \\
\hline & Nuclear & 0.058 & 0.301 & 0.118 & 0.106 & 0.126 & 0.111 & 0.084 & 0.096 \\
\hline & Hydroelectric & 0.103 & 0.014 & 0.014 & 0.027 & 0.085 & 0.144 & 0.296 & 0.407 \\
\hline & Biomass & 0.092 & 0.031 & 0.028 & 0.041 & 0.088 & 0.145 & 0.199 & 0.378 \\
\hline & Wind & 0.045 & 0.017 & 0.015 & 0.025 & 0.054 & 0.113 & 0.191 & 0.540 \\
\hline & Solar & 0.034 & 0.009 & 0.007 & 0.011 & 0.037 & 0.085 & 0.184 & 0.632 \\
\hline & Ocean & 0.109 & 0.017 & 0.015 & 0.028 & 0.078 & 0.129 & 0.184 & 0.440 \\
\hline \multirow[t]{4}{*}{ Question 6 } & $\begin{array}{c}\text { And thinking about energy in } \\
30 \text { years, which do you think } \\
\text { will be the three most used } \\
\text { energy sources in (OUR } \\
\text { COUNTRY)*** }\end{array}$ & $\mathbf{0}$ & 1 & 2 & 3 & & & & \\
\hline & Fossils & 0.607 & 0.259 & 0.115 & 0.019 & & & & \\
\hline & Renew & 0.229 & 0.234 & 0.344 & 0.192 & & & & \\
\hline & Nuclear & 0.669 & 0.331 & & & & & & \\
\hline
\end{tabular}


Table 2 (continued)

\begin{tabular}{|l|l|ccccc|}
\hline Question 7 7 & $\begin{array}{l}\text { To what extent would you } \\
\text { trust information about energy } \\
\text { related issues from each of the } \\
\text { following sources?**** }\end{array}$ & $\begin{array}{c}\mathbf{0} \\
\text { Don't } \\
\text { know }\end{array}$ & $\begin{array}{c}\mathbf{1} \text { Total } \\
\text { trust }\end{array}$ & $\mathbf{2}$ & $\mathbf{3}$ & $\begin{array}{c}\mathbf{4} \\
\text { Not } \\
\text { at all }\end{array}$ \\
\hline & National government & 0.041 & 0.046 & 0.343 & 0.417 & 0.153 \\
& Regional/local government & 0.046 & 0.044 & 0.384 & 0.418 & 0.107 \\
& EU & 0.065 & 0.048 & 0.398 & 0.390 & 0.099 \\
& 0.047 & 0.053 & 0.345 & 0.423 & 0.130 \\
& Electric companies & 0.047 & 0.160 & 0.565 & 0.194 & 0.034 \\
& Scientist & 0.049 & 0.136 & 0.522 & 0.243 & 0.050 \\
& Environmental protection & & & & & \\
& agencies & 0.048 & 0.031 & 0.291 & 0.458 & 0.172 \\
& Journalists & 0.046 & 0.015 & 0.155 & 0.502 & 0.283 \\
\hline
\end{tabular}

Note : all values in percentage

* The relativity scale is as follows: 1 Not at all important; 7 Extremely important; 0 is "don't know" and the corresponding individuals were removed from the econometric analysis

** The relativity scale is as follows: 1 Strongly opposed; 7 Strongly in favour; 0 is "don't know" and the corresponding individuals were removed from the econometric analysis

*** For fossils, the distribution pertains to the number of times a fossil energy (coal, oil or gas) was mentioned. Similarly, for Renew, the distribution pertains to the number of times a renewable energy (hydroelectric, biomass, wind, solar, ocean) was mentioned. Finally, nuclear is a binary variable taking the value of 0 if nuclear was not mentioned and 1 if it was.

**** The relativity scale is as follows: 1 Totally; 2 A lot; 3 Not much; 4 Not at all; 0 is "don't know" and the corresponding individuals were removed from the econometric analysis 
Table 3.

Summary statistics on the explanatory variables.

\begin{tabular}{|c|c|c|c|c|}
\hline \multicolumn{5}{|c|}{ Categorical variables } \\
\hline Category & Variables & Reference & Mean & St. Dev. \\
\hline Gender & $\begin{array}{c}\text { Male } \\
\text { Female }\end{array}$ & $\mathrm{X}$ & 0.540 & \\
\hline Having children & $\begin{array}{c}\text { No children } \\
\text { less than } 10 \\
\text { between } 10 \text { and } 14\end{array}$ & $\mathrm{X}$ & $\begin{array}{l}0.189 \\
0.128\end{array}$ & \\
\hline Occupation* & $\begin{array}{c}\text { Non-active } \\
\text { Agriculture } \\
\text { Professional } \\
\text { Self-employed } \\
\text { Employed professional } \\
\text { Services } \\
\text { Manual worker }\end{array}$ & $\mathrm{X}$ & $\begin{array}{l}0.010 \\
0.018 \\
0.046 \\
0.103 \\
0.196 \\
0.118\end{array}$ & \\
\hline Car ownership & $\begin{array}{l}\text { Yes } \\
\text { No }\end{array}$ & $X$ & 0.771 & \\
\hline Home ownership & $\begin{array}{l}\text { Finished paying for mortgage } \\
\text { Still paying for mortgage } \\
\text { None }\end{array}$ & $X$ & $\begin{array}{l}0.384 \\
0.342\end{array}$ & \\
\hline Computer ownership & $\begin{array}{l}\text { Yes } \\
\text { No }\end{array}$ & $\mathrm{X}$ & 0.622 & \\
\hline Internet connection & $\begin{array}{l}\text { Yes } \\
\text { No }\end{array}$ & $X$ & 0.526 & \\
\hline $\begin{array}{l}\text { Undertaking energy } \\
\text { saving action** }\end{array}$ & $\begin{array}{c}\text { Cut down on heating } \\
\text { Cut down on lighting } \\
\text { Insulated house } \\
\text { Saved energy at work } \\
\text { Use car more efficiently } \\
\text { Use more public transport }\end{array}$ & & $\begin{array}{l}0.427 \\
0.464 \\
0.185 \\
0.733 \\
0.345 \\
0.143\end{array}$ & \\
\hline $\begin{array}{l}\text { Type of community } \\
\text { they live in }\end{array}$ & $\begin{array}{c}\text { Rural } \\
\text { Small urban } \\
\text { Large urban }\end{array}$ & $\mathrm{X}$ & $\begin{array}{l}0.373 \\
0.268\end{array}$ & \\
\hline $\begin{array}{l}\text { Perceptions on most } \\
\text { used fuels*** }\end{array}$ & $\begin{array}{l}\text { Said fossil fuels } \\
\text { Said renewable } \\
\text { Said nuclear }\end{array}$ & & $\begin{array}{l}0.936 \\
0.420 \\
0.339\end{array}$ & \\
\hline Country variable & Austria & $\mathrm{X}$ & & \\
\hline
\end{tabular}

\section{Continuous variables}

$\begin{array}{lrr}\text { Age } & 47 & 18.23 \\ & 28.71 & 25.80\end{array}$

Notes:

* Non-active covers the following four categories in the survey: (1) Responsible for ordinary shopping and looking after the home, or without any current occupation, not working: (2) Student; (3) Unemployed or temporarily not working; (4) Retired or unable to work through illness Agriculture covers self-employed categories of 5 and 6, Farmer and Fisherman. 
Table 4.

Use of energy saving behaviours as explanatory variables.

\begin{tabular}{|c|c|}
\hline $\begin{array}{c}\text { Types of energy saving behaviours } \\
\text { respondents undertaken }\end{array}$ & Variable used in the model \\
\hline Cut down on heating orland air conditioning \\
\hline $\begin{array}{c}\text { Cut down on lighting and the use of domestic } \\
\text { electrical appliances }\end{array}$ & Has cut heating \\
\hline Insulated your house (walls, windows, etc.) & Has insulated house \\
\hline Took initiatives to save energy at work & Has saved energy at work \\
\hline $\begin{array}{c}\text { Used your car less } \\
\text { Reduced your driving speed } \\
\text { Changed your car to another one which uses less } \\
\text { fuel }\end{array}$ & Use car less \\
\hline Used public transport more & Use more public transport \\
\hline
\end{tabular}


Table 5.

Energy related perceptions: ML binary and ordered probit estimation.

\begin{tabular}{|c|c|c|c|c|c|c|}
\hline & \multicolumn{4}{|c|}{ Question 1 (binary probit): National importance of } & \multirow{2}{*}{\multicolumn{2}{|c|}{$\begin{array}{c}\text { Question } 2 \text { (ordered probit) } \\
\text { Importance of reducing energy }\end{array}$}} \\
\hline & \multicolumn{2}{|c|}{ Energy } & \multicolumn{2}{|c|}{ Environment } & & \\
\hline & (1) & (2) & (1) & (2) & (1) & (2) \\
\hline \multirow[t]{2}{*}{ (Intercept) } & $-1.160 * * *$ & $-1.194 * * *$ & $-1.151 * * *$ & $-1.183^{* * *}$ & & \\
\hline & $(0.0910)$ & $(0.0927)$ & $(0.0923)$ & $(0.0948)$ & & \\
\hline \multirow[t]{2}{*}{ Female } & $-0.0961 * * *$ & $-0.108 * * *$ & 0.0445 & 0.0368 & $0.0733^{* * *}$ & $0.0485^{* * *}$ \\
\hline & $(0.0263)$ & $(0.0266)$ & $(0.0270)$ & $(0.0274)$ & $(0.0179)$ & $(0.0180)$ \\
\hline \multirow[t]{2}{*}{ Age } & -0.000535 & -0.00139 & $-0.00174 *$ & $-0.00257 * * *$ & $0.00433 * * *$ & $0.00344 * * *$ \\
\hline & $(0.000903)$ & $(0.000926)$ & $(0.000932)$ & $(0.000958)$ & $(0.000611)$ & $(0.000620)$ \\
\hline \multirow[t]{2}{*}{ Children $<10$} & -0.0242 & -0.0305 & -0.0530 & -0.0572 & -0.0141 & -0.0177 \\
\hline & $(0.0352)$ & $(0.0356)$ & $(0.0363)$ & $(0.0367)$ & $(0.0241)$ & $(0.0241)$ \\
\hline \multirow[t]{2}{*}{ Children 10-14 } & -0.00378 & 0.00145 & -0.00419 & -0.00147 & -0.0433 & -0.0400 \\
\hline & $(0.0389)$ & $(0.0391)$ & $(0.0401)$ & $(0.0404)$ & $(0.0267)$ & $(0.0267)$ \\
\hline \multirow[t]{2}{*}{ Years of education } & $0.00518^{* *}$ & 0.00312 & $0.0122 * * *$ & $0.00923 * * *$ & $0.00644 * * *$ & $0.00453^{* *}$ \\
\hline & $(0.00256)$ & $(0.00262)$ & $(0.00258)$ & $(0.00263)$ & $(0.00200)$ & $(0.00197)$ \\
\hline \multirow[t]{2}{*}{ Agriculture } & 0.0605 & 0.0732 & 0.156 & 0.166 & -0.0712 & -0.0478 \\
\hline & $(0.124)$ & $(0.124)$ & $(0.128)$ & $(0.129)$ & $(0.0862)$ & $(0.0842)$ \\
\hline \multirow[t]{2}{*}{ Professional } & 0.0814 & 0.0431 & $0.197 * *$ & 0.151 & 0.0482 & 0.0201 \\
\hline & $(0.0904)$ & $(0.0904)$ & $(0.0916)$ & $(0.0919)$ & $(0.0720)$ & (0.0709) \\
\hline \multirow[t]{2}{*}{ Self employed } & $0.103^{*}$ & 0.0982 & 0.0341 & 0.0174 & 0.0171 & 0.0343 \\
\hline & $(0.0617)$ & $(0.0620)$ & $(0.0655)$ & $(0.0662)$ & $(0.0416)$ & $(0.0418)$ \\
\hline \multirow[t]{2}{*}{ Employed professional } & $0.0957 * *$ & 0.0686 & $0.0849^{*}$ & 0.0360 & $0.0807 * *$ & $0.0686^{* *}$ \\
\hline & $(0.0447)$ & $(0.0454)$ & $(0.0459)$ & $(0.0469)$ & $(0.0316)$ & $(0.0319)$ \\
\hline \multirow[t]{2}{*}{ Services } & 0.0286 & 0.00922 & $0.0840 * *$ & 0.0494 & 0.0261 & 0.0127 \\
\hline & $(0.0366)$ & $(0.0370)$ & $(0.0370)$ & $(0.0376)$ & $(0.0244)$ & $(0.0247)$ \\
\hline \multirow[t]{2}{*}{ Manual Worker } & 0.00226 & -0.00340 & -0.0309 & -0.0364 & -0.0214 & -0.0137 \\
\hline & $(0.0447)$ & $(0.0450)$ & $(0.0469)$ & $(0.0474)$ & $(0.0301)$ & $(0.0301)$ \\
\hline \multirow[t]{2}{*}{ Owns a car } & $0.100 * * *$ & $0.0644 *$ & 0.0275 & -0.0227 & 0.0201 & -0.00795 \\
\hline & $(0.0370)$ & $(0.0382)$ & $(0.0364)$ & $(0.0378)$ & $(0.0235)$ & $(0.0243)$ \\
\hline \multirow[t]{2}{*}{ Paying lodging } & $0.122 * * *$ & $0.104 * * *$ & -0.0318 & -0.0495 & $0.0482 * *$ & $0.0435^{*}$ \\
\hline & $(0.0353)$ & $(0.0357)$ & $(0.0357)$ & $(0.0362)$ & $(0.0242)$ & $(0.0244)$ \\
\hline \multirow[t]{2}{*}{ Paid lodging } & $0.113^{* * *}$ & $0.0984 * * *$ & 0.0220 & 0.00916 & 0.00531 & 0.0101 \\
\hline & $(0.0366)$ & $(0.0370)$ & $(0.0378)$ & $(0.0384)$ & $(0.0249)$ & $(0.0251)$ \\
\hline Computer & 0.00750 & -0.00945 & 0.0579 & 0.0269 & 0.0379 & 0.0107 \\
\hline & $(0.0481)$ & $(0.0484)$ & $(0.0493)$ & $(0.0496)$ & $(0.0311)$ & $(0.0311)$ \\
\hline Internet & $0.0849 *$ & $0.0831 *$ & 0.0602 & 0.0613 & 0.0295 & 0.0302 \\
\hline & $(0.0453)$ & $(0.0456)$ & $(0.0460)$ & $(0.0463)$ & $(0.0297)$ & $(0.0297)$ \\
\hline Cut heating & & $0.144 * * *$ & & $0.106^{* * * *}$ & & $0.185^{* * *}$ \\
\hline & & $(0.0278)$ & & $(0.0284)$ & & $(0.0187)$ \\
\hline Cut lightning & & $0.0990 * * *$ & & $0.0892 * * *$ & & $0.212 * * *$ \\
\hline & & $(0.0273)$ & & $(0.0281)$ & & $(0.0184)$ \\
\hline Insulated house & & $0.140 * * *$ & & $0.101 * * *$ & & 0.0332 \\
\hline & & $(0.0317)$ & & $(0.0327)$ & & $(0.0232)$ \\
\hline Saved energy & & 0.0295 & & $0.212 * * *$ & & $-0.0650 *$ \\
\hline & & $(0.0467)$ & & $(0.0463)$ & & $(0.0346)$ \\
\hline Less car & & $0.112 * * *$ & & $0.179 * * *$ & & $0.127 * * *$ \\
\hline & & $(0.0288)$ & & $(0.0296)$ & & $(0.0203)$ \\
\hline More public transport & & $0.114 * * *$ & & $0.221 * * *$ & & $0.189 * * *$ \\
\hline & & $(0.0361)$ & & $(0.0357)$ & & $(0.0261)$ \\
\hline Small urban community & $-0.0539 *$ & $-0.0538 *$ & -0.0174 & -0.0241 & -0.0237 & -0.0316 \\
\hline & $(0.0305)$ & $(0.0308)$ & $(0.0315)$ & $(0.0318)$ & $(0.0210)$ & $(0.0210)$ \\
\hline Large urban community & $-0.120 * * *$ & $-0.126 * * *$ & -0.0106 & -0.0325 & $0.0435^{*}$ & 0.0211 \\
\hline & $(0.0347)$ & $(0.0352)$ & $(0.0351)$ & $(0.0356)$ & $(0.0233)$ & $(0.0235)$ \\
\hline Number of observations & 15,559 & 15,559 & 15,559 & 15,559 & 15,166 & 15,166 \\
\hline
\end{tabular}


Table 6.

Energy policy priorities: ML probit estimation.

\begin{tabular}{|c|c|c|c|c|c|c|c|c|c|c|c|c|}
\hline \multirow[b]{3}{*}{ (Intercept) } & \multicolumn{2}{|c|}{$\begin{array}{c}\text { Guaranteeing low prices for } \\
\text { consumers }\end{array}$} & \multicolumn{2}{|c|}{$\begin{array}{l}\text { Guaranteeing a continuous } \\
\text { supply of energy }\end{array}$} & \multicolumn{2}{|c|}{$\begin{array}{l}\text { Guaranteeing independence } \\
\text { in the field of energy }\end{array}$} & \multicolumn{2}{|c|}{ Protecting the environment } & \multicolumn{2}{|c|}{$\begin{array}{l}\text { Guaranteeing the } \\
\text { competitiveness of our } \\
\text { industries }\end{array}$} & \multicolumn{2}{|c|}{ Reduce energy consumption } \\
\hline & (1) & (2) & (1) & (2) & (1) & (2) & (1) & (2) & (1) & (2) & (1) & (2) \\
\hline & $\begin{array}{c}0.306 * * * \\
(0.0842)\end{array}$ & $\begin{array}{c}0.314 * * * \\
(0.0844)\end{array}$ & $\begin{array}{c}-0.758^{* * * *} \\
(0.0777)\end{array}$ & $\begin{array}{c}-0.760 * * * \\
(0.0782)\end{array}$ & $\begin{array}{c}-0.911 * * * \\
(0.0849)\end{array}$ & $\begin{array}{c}-0.913 * * * \\
(0.0858)\end{array}$ & $\begin{array}{c}-0.755^{* * *} * \\
(0.0801)\end{array}$ & $\begin{array}{c}-0.794 * * * \\
(0.0808)\end{array}$ & $\begin{array}{c}-1.538^{* * * *} \\
(0.105)\end{array}$ & $\begin{array}{c}-1.499 * * * \\
(0.106)\end{array}$ & $\begin{array}{c}-1.288^{* * * *} \\
(0.0889)\end{array}$ & $\begin{array}{c}-1.335 * * * \\
(0.0899)\end{array}$ \\
\hline Female & $\begin{array}{c}0.0348 \\
(0.0218)\end{array}$ & $\begin{array}{c}0.0251 \\
(0.0220)\end{array}$ & $\begin{array}{c}-0.114 * * * \\
(0.0215)\end{array}$ & $\begin{array}{c}-0.118 * * * \\
(0.0216)\end{array}$ & $\begin{array}{c}-0.122 * * * \\
(0.0246)\end{array}$ & $\begin{array}{c}-0.124 * * * \\
(0.0248)\end{array}$ & $\begin{array}{c}0.0875 * * * \\
(0.0224)\end{array}$ & $\begin{array}{c}0.0832 * * * \\
(0.0226)\end{array}$ & $\begin{array}{c}-0.179 * * * \\
(0.0304)\end{array}$ & $\begin{array}{c}-0.163 * * * \\
(0.0306)\end{array}$ & $\begin{array}{c}-0.0584 * * \\
(0.0256)\end{array}$ & $\begin{array}{c}-0.0700^{* * * * *} \\
(0.0258)\end{array}$ \\
\hline Age & $\begin{array}{c}0.000515 \\
(0.000742)\end{array}$ & $\begin{array}{c}0.000540 \\
(0.000750)\end{array}$ & $\begin{array}{c}0.00613 * * * \\
(0.000743)\end{array}$ & $\begin{array}{c}0.00627 * * * \\
(0.000749)\end{array}$ & $\begin{array}{c}0.00262 * * * \\
(0.000831)\end{array}$ & $\begin{array}{c}0.00229 * * * \\
(0.000842)\end{array}$ & $\begin{array}{c}-0.00832 * * * \\
(0.000765)\end{array}$ & $\begin{array}{c}-0.00832 * * * \\
(0.000771)\end{array}$ & $\begin{array}{l}0.000255 \\
(0.00102)\end{array}$ & $\begin{array}{l}0.000198 \\
(0.00103)\end{array}$ & $\begin{array}{l}-0.000226 \\
(0.000877)\end{array}$ & $\begin{array}{c}-0.000693 \\
(0.000893)\end{array}$ \\
\hline Children $<10$ & $\begin{array}{c}0.126 * * * \\
(0.0295)\end{array}$ & $\begin{array}{c}0.123 * * * \\
(0.0296)\end{array}$ & $\begin{array}{l}0.00522 \\
(0.0296)\end{array}$ & $\begin{array}{l}0.00355 \\
(0.0297)\end{array}$ & $\begin{array}{l}-0.0513 \\
(0.0339)\end{array}$ & $\begin{array}{c}-0.0593^{*} \\
(0.0340)\end{array}$ & $\begin{array}{l}-0.0551^{*} \\
(0.0296)\end{array}$ & $\begin{array}{l}-0.0503^{*} \\
(0.0297)\end{array}$ & $\begin{array}{l}-0.0651 \\
(0.0417)\end{array}$ & $\begin{array}{l}-0.0639 \\
(0.0418)\end{array}$ & $\begin{array}{l}-0.0214 \\
(0.0347)\end{array}$ & $\begin{array}{l}-0.0213 \\
(0.0349)\end{array}$ \\
\hline Children 10-14 & $\begin{array}{l}-0.0420 \\
(0.0335)\end{array}$ & $\begin{array}{l}-0.0455 \\
(0.0336)\end{array}$ & $\begin{array}{c}-0.0974 * * * * \\
(0.0330)\end{array}$ & $\begin{array}{c}-0.0997 * * * * \\
(0.0331)\end{array}$ & $\begin{array}{c}0.0422 \\
(0.0370)\end{array}$ & $\begin{array}{c}0.0417 \\
(0.0370)\end{array}$ & $\begin{array}{c}0.0528 \\
(0.0331)\end{array}$ & $\begin{array}{l}0.0554 * \\
(0.0332)\end{array}$ & $\begin{array}{l}-0.112 * * \\
(0.0475)\end{array}$ & $\begin{array}{l}-0.109 * * \\
(0.0476)\end{array}$ & $\begin{array}{l}-0.0251 \\
(0.0383)\end{array}$ & $\begin{array}{l}-0.0197 \\
(0.0385)\end{array}$ \\
\hline Years of education & $\begin{array}{c}-0.0262 * * * \\
(0.00282)\end{array}$ & $\begin{array}{c}-0.0250 * * * \\
(0.00280)\end{array}$ & $\begin{array}{c}0.00486 * * \\
(0.00219)\end{array}$ & $\begin{array}{c}0.00572 * * * \\
(0.00220)\end{array}$ & $\begin{array}{c}0.00602 * * \\
(0.00241)\end{array}$ & $\begin{array}{c}0.00570 * * \\
(0.00242)\end{array}$ & $\begin{array}{c}0.0117 * * * \\
(0.00224)\end{array}$ & $\begin{array}{c}0.0106 * * * \\
(0.00225)\end{array}$ & $\begin{array}{l}0.00461 * \\
(0.00278)\end{array}$ & $\begin{array}{c}0.00431 \\
(0.00279)\end{array}$ & $\begin{array}{c}0.0164 * * * \\
(0.00243)\end{array}$ & $\begin{array}{c}0.0146 * * * \\
(0.00245)\end{array}$ \\
\hline Agriculture & $\begin{array}{l}-0.0200 \\
(0.105)\end{array}$ & $\begin{array}{c}-0.00298 \\
(0.106)\end{array}$ & $\begin{array}{l}0.0120 \\
(0.106)\end{array}$ & $\begin{array}{l}0.0158 \\
(0.106)\end{array}$ & $\begin{array}{l}0.215^{*} \\
(0.114)\end{array}$ & $\begin{array}{l}0.212 * \\
(0.114)\end{array}$ & $\begin{array}{l}-0.168 \\
(0.125)\end{array}$ & $\begin{array}{l}-0.169 \\
(0.126)\end{array}$ & $\begin{array}{l}0.0673 \\
(0.142)\end{array}$ & $\begin{array}{l}0.0512 \\
(0.141)\end{array}$ & $\begin{array}{c}0.316^{* * * *} \\
(0.119)\end{array}$ & $\begin{array}{c}0.326 * * * \\
(0.117)\end{array}$ \\
\hline Professional & $\begin{array}{c}-0.0598 \\
(0.0814)\end{array}$ & $\begin{array}{l}-0.0279 \\
(0.0824)\end{array}$ & $\begin{array}{c}0.0809 \\
(0.0785)\end{array}$ & $\begin{array}{c}0.0972 \\
(0.0785)\end{array}$ & $\begin{array}{l}-0.00912 \\
(0.0903)\end{array}$ & $\begin{array}{l}-0.0173 \\
(0.0908)\end{array}$ & $\begin{array}{l}-0.0736 \\
(0.0835)\end{array}$ & $\begin{array}{l}-0.0975 \\
(0.0831)\end{array}$ & $\begin{array}{l}0.237 * * \\
(0.0971)\end{array}$ & $\begin{array}{l}0.233^{* *} \\
(0.0978)\end{array}$ & $\begin{array}{c}0.0160 \\
(0.0883)\end{array}$ & $\begin{array}{l}-0.0164 \\
(0.0886)\end{array}$ \\
\hline Self employed & $\begin{array}{c}-0.101 * \\
(0.0524)\end{array}$ & $\begin{array}{c}-0.0812 \\
(0.0526)\end{array}$ & $\begin{array}{c}0.0171 \\
(0.0515)\end{array}$ & $\begin{array}{c}0.0261 \\
(0.0519)\end{array}$ & $\begin{array}{l}0.0982^{*} \\
(0.0574)\end{array}$ & $\begin{array}{c}0.0921 \\
(0.0576)\end{array}$ & $\begin{array}{l}-0.0372 \\
(0.0543)\end{array}$ & $\begin{array}{l}-0.0412 \\
(0.0546)\end{array}$ & $\begin{array}{l}0.146^{* * *} \\
(0.0684)\end{array}$ & $\begin{array}{l}0.139 * * \\
(0.0688)\end{array}$ & $\begin{array}{c}0.0253 \\
(0.0610)\end{array}$ & $\begin{array}{c}0.0255 \\
(0.0614)\end{array}$ \\
\hline Employed professional & $\begin{array}{c}-0.170^{* * * *} \\
(0.0408)\end{array}$ & $\begin{array}{c}-0.138^{* * * * *} \\
(0.0413)\end{array}$ & $\begin{array}{l}0.0631^{*} \\
(0.0381)\end{array}$ & $\begin{array}{c}0.0785 * * \\
(0.0384)\end{array}$ & $\begin{array}{c}0.112 * * * \\
(0.0433)\end{array}$ & $\begin{array}{l}0.103 * * \\
(0.0436)\end{array}$ & $\begin{array}{c}0.0559 \\
(0.0389)\end{array}$ & $\begin{array}{c}0.0345 \\
(0.0393)\end{array}$ & $\begin{array}{c}0.0169 \\
(0.0518)\end{array}$ & $\begin{array}{c}0.0111 \\
(0.0524)\end{array}$ & $\begin{array}{c}0.0909^{* *} \\
(0.0429)\end{array}$ & $\begin{array}{c}0.0703 \\
(0.0434)\end{array}$ \\
\hline Services & $\begin{array}{c}-0.0520^{*} \\
(0.0304)\end{array}$ & $\begin{array}{c}-0.0319 \\
(0.0306)\end{array}$ & $\begin{array}{l}-0.0339 \\
(0.0302)\end{array}$ & $\begin{array}{l}-0.0232 \\
(0.0304)\end{array}$ & $\begin{array}{c}0.0962 * * * \\
(0.0345)\end{array}$ & $\begin{array}{c}0.0873^{* *} \\
(0.0348)\end{array}$ & $\begin{array}{c}0.0618^{* * *} \\
(0.0305)\end{array}$ & $\begin{array}{c}0.0474 \\
(0.0307)\end{array}$ & $\begin{array}{l}-0.0115 \\
(0.0427)\end{array}$ & $\begin{array}{l}-0.0141 \\
(0.0431)\end{array}$ & $\begin{array}{c}0.0211 \\
(0.0351)\end{array}$ & $\begin{array}{l}0.00468 \\
(0.0354)\end{array}$ \\
\hline Manual Worker & $\begin{array}{l}0.176 * * * * \\
(0.0361)\end{array}$ & $\begin{array}{c}0.186 * * * \\
(0.0363)\end{array}$ & $\begin{array}{l}0.00284 \\
(0.0362)\end{array}$ & $\begin{array}{l}0.00587 \\
(0.0363)\end{array}$ & $\begin{array}{c}0.0370 \\
(0.0417)\end{array}$ & $\begin{array}{c}0.0306 \\
(0.0418)\end{array}$ & $\begin{array}{l}-0.0682^{*} \\
(0.0373)\end{array}$ & $\begin{array}{l}-0.0685^{*} \\
(0.0374)\end{array}$ & $\begin{array}{l}-0.0112 \\
(0.0524)\end{array}$ & $\begin{array}{l}-0.0165 \\
(0.0528)\end{array}$ & $\begin{array}{c}-0.126 * * * \\
(0.0451)\end{array}$ & $\begin{array}{c}-0.125 * * * \\
(0.0454)\end{array}$ \\
\hline Owns a car & $\begin{array}{l}-0.0287 \\
(0.0284)\end{array}$ & $\begin{array}{c}-0.00902 \\
(0.0293)\end{array}$ & $\begin{array}{l}0.110 * * * * \\
(0.0286)\end{array}$ & $\begin{array}{l}0.127 * * * * \\
(0.0295)\end{array}$ & $\begin{array}{c}0.114 * * * \\
(0.0333)\end{array}$ & $\begin{array}{c}0.0944 * * * \\
(0.0344)\end{array}$ & $\begin{array}{c}0.0244 \\
(0.0296)\end{array}$ & $\begin{array}{c}0.0262 \\
(0.0306)\end{array}$ & $\begin{array}{l}0.102 * * \\
(0.0423)\end{array}$ & $\begin{array}{l}0.0805^{*} \\
(0.0440)\end{array}$ & $\begin{array}{c}-0.0831 * * \\
(0.0344)\end{array}$ & $\begin{array}{c}-0.109 * * * \\
(0.0358)\end{array}$ \\
\hline Paying lodging & $\begin{array}{c}-0.0975 * * * \\
(0.0296)\end{array}$ & $\begin{array}{c}-0.0936^{* * *} \\
(0.0298)\end{array}$ & $\begin{array}{c}0.102 * * * \\
(0.0292)\end{array}$ & $\begin{array}{c}0.106^{* * * *} \\
(0.0294)\end{array}$ & $\begin{array}{l}0.0648^{*} \\
(0.0336)\end{array}$ & $\begin{array}{l}0.0564^{*} \\
(0.0338)\end{array}$ & $\begin{array}{l}-0.0280 \\
(0.0299)\end{array}$ & $\begin{array}{c}-0.0272 \\
(0.0301)\end{array}$ & $\begin{array}{c}0.0646 \\
(0.0419)\end{array}$ & $\begin{array}{c}0.0560 \\
(0.0424)\end{array}$ & $\begin{array}{c}0.0920 * * * \\
(0.0340)\end{array}$ & $\begin{array}{c}0.0864 * * \\
(0.0344)\end{array}$ \\
\hline Paid lodging & $\begin{array}{c}-0.157 * * * \\
(0.0299)\end{array}$ & $\begin{array}{c}-0.151 * * * \\
(0.0300)\end{array}$ & $\begin{array}{c}0.0883 * * * \\
(0.0298)\end{array}$ & $\begin{array}{c}0.0913 * * * \\
(0.0300)\end{array}$ & $\begin{array}{c}0.101 * * * \\
(0.0336)\end{array}$ & $\begin{array}{c}0.0942 * * * \\
(0.0339)\end{array}$ & $\begin{array}{l}-0.0324 \\
(0.0309)\end{array}$ & $\begin{array}{l}-0.0311 \\
(0.0311)\end{array}$ & $\begin{array}{l}0.0718^{*} \\
(0.0420)\end{array}$ & $\begin{array}{c}0.0623 \\
(0.0423)\end{array}$ & $\begin{array}{l}-0.0144 \\
(0.0356)\end{array}$ & $\begin{array}{l}-0.0173 \\
(0.0359)\end{array}$ \\
\hline Computer & $\begin{array}{c}-4.83 \mathrm{e}-05 \\
(0.0374)\end{array}$ & $\begin{array}{c}0.0120 \\
(0.0375)\end{array}$ & $\begin{array}{c}0.0917 * * \\
(0.0377)\end{array}$ & $\begin{array}{c}0.0998 * * * \\
(0.0378)\end{array}$ & $\begin{array}{c}0.0367 \\
(0.0426)\end{array}$ & $\begin{array}{c}0.0325 \\
(0.0427)\end{array}$ & $\begin{array}{c}0.0522 \\
(0.0388)\end{array}$ & $\begin{array}{c}0.0390 \\
(0.0388)\end{array}$ & $\begin{array}{c}0.0582 \\
(0.0548)\end{array}$ & $\begin{array}{c}0.0575 \\
(0.0550)\end{array}$ & $\begin{array}{c}0.0161 \\
(0.0458)\end{array}$ & $\begin{array}{c}-0.00512 \\
(0.0460)\end{array}$ \\
\hline Internet & $\begin{array}{c}-0.173 * * * \\
(0.0360)\end{array}$ & $\begin{array}{c}-0.171 * * * \\
(0.0361)\end{array}$ & $\begin{array}{l}-0.0109 \\
(0.0360)\end{array}$ & $\begin{array}{c}-0.00971 \\
(0.0361)\end{array}$ & $\begin{array}{l}-0.0177 \\
(0.0408)\end{array}$ & $\begin{array}{l}-0.0184 \\
(0.0408)\end{array}$ & $\begin{array}{c}0.0162 \\
(0.0370)\end{array}$ & $\begin{array}{c}0.0166 \\
(0.0370)\end{array}$ & $\begin{array}{c}0.0682 \\
(0.0510)\end{array}$ & $\begin{array}{c}0.0657 \\
(0.0510)\end{array}$ & $\begin{array}{c}0.118 * * * \\
(0.0431)\end{array}$ & $\begin{array}{c}0.116 * * * \\
(0.0433)\end{array}$ \\
\hline Cut heating & & $\begin{array}{c}0.0608 * * * \\
(0.0233)\end{array}$ & & $\begin{array}{l}0.00724 \\
(0.0230)\end{array}$ & & $\begin{array}{c}-0.0317 \\
(0.0263)\end{array}$ & & $\begin{array}{l}0.00665 \\
(0.0238)\end{array}$ & & $\begin{array}{l}-0.0623^{*} \\
(0.0327)\end{array}$ & & $\begin{array}{c}0.105 * * * \\
(0.0270)\end{array}$ \\
\hline Cut lightning & & $\begin{array}{c}0.0332 \\
(0.0227)\end{array}$ & & $\begin{array}{c}0.0160 \\
(0.0224)\end{array}$ & & $\begin{array}{c}0.0790 * * * \\
(0.0256)\end{array}$ & & $\begin{array}{l}0.0409^{*} \\
(0.0233)\end{array}$ & & $\begin{array}{c}-0.127 \text { *** } \\
(0.0319)\end{array}$ & & $\begin{array}{c}0.0796 * * * \\
(0.0267)\end{array}$ \\
\hline Insulated house & & $\begin{array}{l}-0.0399 \\
(0.0285)\end{array}$ & & $\begin{array}{l}-0.0177 \\
(0.0278)\end{array}$ & & $\begin{array}{l}0.0728 * * \\
(0.0313)\end{array}$ & & $\begin{array}{l}-0.0103 \\
(0.0290)\end{array}$ & & $\begin{array}{l}0.0624^{*} \\
(0.0377)\end{array}$ & & $\begin{array}{c}0.0319 \\
(0.0322)\end{array}$ \\
\hline Saved energy & & $-0.264 * * *$ & & -0.100 ** & & 0.0190 & & $0.152 * * *$ & & 0.0686 & & 0.0550 \\
\hline
\end{tabular}


Table 6 (continued)

\begin{tabular}{|c|c|c|c|c|c|c|c|c|c|c|c|c|}
\hline \multirow{3}{*}{ Less car } & & $(0.0443)$ & & $(0.0419)$ & & $(0.0470)$ & & $(0.0417)$ & & $(0.0560)$ & & $(0.0458)$ \\
\hline & & $-0.109 * * *$ & & $-0.0783 * * *$ & & $0.0575 * *$ & & 0.0386 & & $0.0711^{* *}$ & & $0.111 * * *$ \\
\hline & & $(0.0250)$ & & $(0.0245)$ & & $(0.0280)$ & & $(0.0254)$ & & $(0.0342)$ & & $(0.0284)$ \\
\hline More public transport & & $-0.140 * * *$ & & $-0.0799 * *$ & & -0.0540 & & $0.181 * * *$ & & 0.00882 & & $0.175 * * *$ \\
\hline & & $(0.0319)$ & & $(0.0311)$ & & $(0.0364)$ & & $(0.0312)$ & & $(0.0444)$ & & $-0.0706 * *$ \\
\hline Small urban community & -0.0163 & -0.0142 & 0.0254 & 0.0269 & 0.0392 & 0.0455 & 0.0265 & 0.0206 & $-0.0979 * * *$ & $-0.0968 * * *$ & $-0.0638 * *$ & $(0.0304)$ \\
\hline & $(0.0255)$ & $(0.0256)$ & $(0.0254)$ & $(0.0254)$ & $(0.0291)$ & $(0.0292)$ & $(0.0264)$ & $(0.0265)$ & $(0.0355)$ & $(0.0356)$ & $(0.0302)$ & -0.0369 \\
\hline Large urban community & $-0.100 * * *$ & $-0.0904 * * *$ & 0.0420 & $0.0487^{*}$ & 0.0236 & 0.0322 & $0.119 * * *$ & $0.101 * * *$ & -0.0634 & -0.0621 & -0.0168 & $(0.0340)$ \\
\hline & $(0.0287)$ & $(0.0289)$ & $(0.0284)$ & $(0.0286)$ & $(0.0328)$ & $(0.0331)$ & $(0.0292)$ & $(0.0294)$ & $(0.0401)$ & $(0.0404)$ & $(0.0337)$ & $(0.0345)$ \\
\hline No of observations & 15,559 & 15,559 & 15,559 & 15,559 & 15,559 & 15,559 & 15,559 & 15,559 & 15,559 & 15,559 & 15,559 & 15,559 \\
\hline
\end{tabular}

Note: clustered by country robust standard errors in brackets. $* * * 1 \%$ significance, $* * 5 \%$ significance, $* 10 \%$ significance 
Table 7.

Conceptualisation of energy system: ML probit estimation.

\begin{tabular}{|c|c|c|c|c|c|c|c|c|c|c|c|c|}
\hline \multirow[b]{3}{*}{ (Intercept) } & \multicolumn{2}{|c|}{ Nuclear energy } & \multicolumn{2}{|c|}{ Electricity supply } & \multicolumn{2}{|c|}{ Fuel } & \multicolumn{2}{|c|}{ Gas } & \multicolumn{2}{|c|}{ Renewable energies } & \multicolumn{2}{|c|}{ Energy consumption } \\
\hline & (1) & (2) & (1) & (2) & (1) & (2) & (1) & (2) & (1) & (2) & (1) & (2) \\
\hline & $-1.477 * * *$ & $-1.502 * * *$ & $-0.579 * * *$ & $-0.595 * * *$ & $-2.186 * * * *$ & $-2.138 * * *$ & $-1.696^{* * * * *}$ & $-1.692^{* * * *}$ & $-0.733 * * * *$ & $-0.754 * * * *$ & $-1.653^{* * * *}$ & $-1.708 * * * *$ \\
\hline & $(0.105)$ & $(0.106)$ & $(0.101)$ & $(0.101)$ & $(0.145)$ & $(0.145)$ & $(0.136)$ & $(0.137)$ & $(0.0859)$ & $(0.0868)$ & $(0.124)$ & $(0.126)$ \\
\hline Female & $\begin{array}{c}-0.205^{* * * *} \\
(0.0307)\end{array}$ & $\begin{array}{c}-0.209 * * * \\
(0.0309)\end{array}$ & $\begin{array}{c}0.0830^{* * * *} \\
(0.0274)\end{array}$ & $\begin{array}{c}0.0803 * * * \\
(0.0275)\end{array}$ & $\begin{array}{c}-0.131 * * * \\
(0.0344)\end{array}$ & $\begin{array}{c}-0.125^{* * * *} \\
(0.0347)\end{array}$ & $\begin{array}{l}-0.0562 \\
(0.0385)\end{array}$ & $\begin{array}{l}-0.0515 \\
(0.0386)\end{array}$ & $\begin{array}{c}-0.0841^{* * *} * \\
(0.0254)\end{array}$ & $\begin{array}{c}-0.0922 * * * \\
(0.0256)\end{array}$ & $\begin{array}{c}0.0988^{* * * *} \\
(0.0360)\end{array}$ & $\begin{array}{c}0.0854 * * \\
(0.0363)\end{array}$ \\
\hline \multirow[t]{2}{*}{ Age } & 0.000654 & 0.000613 & 0.000498 & 0.000797 & $0.00200 *$ & 0.00173 & -0.000154 & 0.000101 & $-0.00462 * * *$ & $-0.00506^{* * *}$ & 0.00158 & 0.00110 \\
\hline & $(0.00107)$ & $(0.00108)$ & $(0.000947)$ & $(0.000951)$ & $(0.00118)$ & $(0.00120)$ & $(0.00129)$ & $(0.00130)$ & $(0.000859)$ & $(0.000870)$ & $(0.00121)$ & $(0.00122)$ \\
\hline \multirow[t]{2}{*}{ Children $<10$} & $-0.0750^{*}$ & $-0.0731^{*}$ & 0.0465 & 0.0476 & -0.0591 & -0.0584 & 0.0164 & 0.0194 & $-0.0961 * * *$ & $-0.0972 * * *$ & 0.0108 & 0.00760 \\
\hline & $(0.0428)$ & $(0.0429)$ & $(0.0370)$ & $(0.0370)$ & $(0.0471)$ & $(0.0472)$ & $(0.0513)$ & $(0.0514)$ & $(0.0340)$ & $(0.0340)$ & $(0.0474)$ & $(0.0478)$ \\
\hline \multirow[t]{2}{*}{ Children 10-14 } & -0.0329 & -0.0313 & 0.0477 & 0.0471 & $-0.121 * *$ & $-0.118 * *$ & -0.0155 & -0.0168 & -0.0201 & -0.0171 & -0.0515 & -0.0537 \\
\hline & $(0.0479)$ & $(0.0479)$ & $(0.0412)$ & $(0.0412)$ & $(0.0557)$ & $(0.0558)$ & $(0.0586)$ & $(0.0586)$ & $(0.0378)$ & $(0.0378)$ & $(0.0540)$ & $(0.0540)$ \\
\hline \multirow[t]{2}{*}{ Years of education } & $0.0104 * * *$ & $0.00971 * * *$ & $-0.00592^{*}$ & -0.00529 & -0.00166 & -0.00227 & 0.00204 & 0.00224 & $0.0161^{* * *}$ & $0.0153^{* * * *}$ & $0.00971^{* *}$ & $0.00862 * *$ \\
\hline & $(0.00281)$ & $(0.00283)$ & $(0.00328)$ & $(0.00327)$ & $(0.00413)$ & $(0.00415)$ & $(0.00422)$ & $(0.00422)$ & $(0.00246)$ & $(0.00248)$ & $(0.00382)$ & $(0.00393)$ \\
\hline \multirow[t]{2}{*}{ Agriculture } & -0.224 & -0.212 & -0.211 & -0.203 & -0.200 & -0.213 & -0.0366 & -0.0356 & -0.0964 & -0.0806 & -0.0658 & -0.0576 \\
\hline & $(0.191)$ & $(0.191)$ & $(0.139)$ & $(0.140)$ & $(0.145)$ & $(0.146)$ & $(0.171)$ & $(0.170)$ & $(0.130)$ & $(0.131)$ & $(0.203)$ & $(0.203)$ \\
\hline \multirow[t]{2}{*}{ Professional } & -0.0452 & -0.0501 & $-0.306 * *$ & $-0.296 * *$ & -0.226 & $-0.239^{*}$ & $-0.381 * *$ & $-0.375^{* *}$ & 0.0287 & 0.0203 & -0.0246 & -0.0479 \\
\hline & $(0.107)$ & $(0.107)$ & $(0.124)$ & $(0.125)$ & $(0.144)$ & $(0.144)$ & $(0.186)$ & $(0.186)$ & $(0.0920)$ & $(0.0923)$ & $(0.122)$ & $(0.122)$ \\
\hline \multirow[t]{2}{*}{ Self employed } & -0.0487 & -0.0422 & 0.0134 & 0.0148 & -0.0221 & -0.0327 & -0.0886 & -0.0856 & 0.0299 & 0.0406 & -0.0466 & -0.0383 \\
\hline & $(0.0761)$ & $(0.0765)$ & $(0.0667)$ & $(0.0669)$ & $(0.0813)$ & $(0.0813)$ & $(0.0906)$ & (0.0910) & $(0.0600)$ & $(0.0603)$ & $(0.0882)$ & $(0.0890)$ \\
\hline \multirow[t]{2}{*}{ Employed professional } & -0.0868 & $-0.0892^{*}$ & -0.156 **** & $-0.151 * * *$ & 0.0649 & 0.0572 & $-0.142 *$ & $-0.134 *$ & $0.103^{* *}$ & $0.102^{* *}$ & $0.140^{* * *}$ & $0.126^{* *}$ \\
\hline & $(0.0532)$ & $(0.0537)$ & $(0.0521)$ & $(0.0526)$ & $(0.0642)$ & $(0.0648)$ & $(0.0737)$ & $(0.0737)$ & (0.0434) & $(0.0436)$ & $(0.0608)$ & $(0.0616)$ \\
\hline \multirow[t]{2}{*}{ Services } & -0.0133 & -0.0136 & -0.0128 & -0.00854 & 0.00344 & 0.00199 & -0.0232 & -0.0164 & 0.0190 & 0.0171 & 0.0460 & 0.0350 \\
\hline & $(0.0422)$ & $(0.0426)$ & $(0.0380)$ & $(0.0382)$ & $(0.0487)$ & $(0.0491)$ & $(0.0530)$ & $(0.0532)$ & $(0.0351)$ & $(0.0353)$ & (0.0494) & $(0.0497)$ \\
\hline \multirow[t]{2}{*}{ Manual Worker } & $-0.128 * *$ & $-0.122 * *$ & 0.00604 & 0.00786 & 0.0401 & 0.0353 & 0.0583 & 0.0603 & -0.0653 & -0.0587 & 0.0614 & 0.0658 \\
\hline & $(0.0546)$ & $(0.0548)$ & $(0.0445)$ & $(0.0446)$ & $(0.0587)$ & $(0.0590)$ & $(0.0633)$ & $(0.0637)$ & (0.0434) & $(0.0436)$ & $(0.0593)$ & $(0.0595)$ \\
\hline \multirow[t]{2}{*}{ Owns a car } & 0.0585 & 0.0486 & -0.0398 & -0.0222 & $0.154^{* * * *}$ & $0.123 * *$ & 0.0565 & 0.0668 & 0.0460 & 0.0271 & 0.0409 & 0.0342 \\
\hline & $(0.0421)$ & $(0.0434)$ & $(0.0351)$ & $(0.0362)$ & $(0.0466)$ & $(0.0481)$ & $(0.0505)$ & $(0.0522)$ & $(0.0341)$ & $(0.0351)$ & $(0.0489)$ & $(0.0503)$ \\
\hline \multirow[t]{2}{*}{ Paying lodging } & $-0.0842^{* *}$ & $-0.0800^{*}$ & $-0.0799 * *$ & $-0.0715^{*}$ & 0.0525 & 0.0518 & 0.0156 & 0.0167 & 0.0489 & 0.0487 & 0.0465 & 0.0447 \\
\hline & $(0.0413)$ & $(0.0417)$ & $(0.0370)$ & $(0.0371)$ & $(0.0483)$ & $(0.0486)$ & $(0.0505)$ & $(0.0507)$ & $(0.0337)$ & $(0.0339)$ & $(0.0464)$ & $(0.0467)$ \\
\hline \multirow[t]{2}{*}{ Paid lodging } & -0.0209 & -0.0176 & $-0.0932 * *$ & $-0.0870 * *$ & $0.0816^{*}$ & $0.0863^{*}$ & 0.0719 & 0.0693 & 0.0477 & 0.0510 & 0.0456 & 0.0441 \\
\hline & $(0.0426)$ & $(0.0429)$ & $(0.0380)$ & $(0.0382)$ & $(0.0466)$ & $(0.0467)$ & $(0.0538)$ & $(0.0538)$ & $(0.0349)$ & $(0.0350)$ & $(0.0477)$ & $(0.0481)$ \\
\hline Computer & $0.114 * *$ & $0.105^{*}$ & -0.000322 & 0.00575 & 0.0862 & 0.0865 & 0.0211 & 0.0265 & $0.0934 * *$ & $0.0823^{*}$ & 0.0770 & 0.0598 \\
\hline & $(0.0558)$ & $(0.0558)$ & $(0.0466)$ & $(0.0467)$ & $(0.0578)$ & $(0.0581)$ & $(0.0646)$ & $(0.0647)$ & $(0.0445)$ & $(0.0445)$ & $(0.0605)$ & $(0.0605)$ \\
\hline Internet & 0.0852 & $0.0866^{*}$ & $-0.0764^{*}$ & $-0.0752 *$ & 0.00400 & 0.00261 & -0.0670 & -0.0663 & -0.00259 & -0.00273 & 0.0138 & 0.0115 \\
\hline & $(0.0519)$ & $(0.0519)$ & $(0.0454)$ & $(0.0455)$ & $(0.0554)$ & $(0.0554)$ & $(0.0629)$ & $(0.0629)$ & $(0.0419)$ & $(0.0419)$ & $(0.0567)$ & $(0.0569)$ \\
\hline Cut heating & & 0.00864 & & $-0.0497^{*}$ & & $0.0877 * *$ & & -0.0265 & & $0.0706 * * *$ & & $0.0633^{*}$ \\
\hline & & $(0.0327)$ & & $(0.0294)$ & & $(0.0365)$ & & $(0.0410)$ & & $(0.0272)$ & & $(0.0383)$ \\
\hline Cut lightning & & 0.0334 & & 0.0254 & & $-0.103 * * *$ & & -0.0538 & & $0.0550^{* *}$ & & $0.163 * * *$ \\
\hline & & (0.0319) & & $(0.0283)$ & & $(0.0366)$ & & $(0.0393)$ & & $(0.0265)$ & & $(0.0369)$ \\
\hline Insulated house & & -0.0232 & & $-0.0604 *$ & & -0.0271 & & 0.00831 & & 0.0132 & & 0.0421 \\
\hline & & $(0.0389)$ & & $(0.0362)$ & & $(0.0434)$ & & $(0.0472)$ & & $(0.0323)$ & & $(0.0456)$ \\
\hline Saved energy & & -0.00143 & & 0.0124 & & 0.0448 & & -0.0126 & & $-0.0823^{*}$ & & 0.0423 \\
\hline & & $(0.0578)$ & & $(0.0553)$ & & $(0.0678)$ & & $(0.0761)$ & & $(0.0478)$ & & $(0.0638)$ \\
\hline Less car & & $0.0578^{*}$ & & $-0.0557^{*}$ & & $0.0826^{* *}$ & & -0.0408 & & $0.0752^{* * * *}$ & & 0.0363 \\
\hline
\end{tabular}


Table 7 (continued)

\begin{tabular}{|c|c|c|c|c|c|c|c|c|c|c|c|c|}
\hline & & $(0.0341)$ & & $(0.0320)$ & & $(0.0395)$ & & $(0.0445)$ & & $(0.0285)$ & & $(0.0404)$ \\
\hline More public transport & & $0.106 * *$ & & $\begin{array}{r}-0.00891 \\
(0.0397)\end{array}$ & & $\begin{array}{l}-0.0691 \\
-0.0529)\end{array}$ & & $\begin{array}{l}0.0241 \\
(0.0539)\end{array}$ & & $0.0886 * *$ & & $0.0893^{*}$ \\
\hline \multirow[t]{2}{*}{ Small urban community } & $0.0954 * * *$ & 0.0896 ** & 0.0297 & 0.0301 & -0.0224 & -0.0240 & $0.0879 *$ & $0.0858^{*}$ & 0.00404 & -0.000602 & $0.121^{* * *}$ & $0.119^{* * *}$ \\
\hline & $(0.0368)$ & $(0.0369)$ & $(0.0311)$ & $(0.0312)$ & $(0.0410)$ & $(0.0411)$ & $(0.0463)$ & $(0.0464)$ & $(0.0300)$ & $(0.0301)$ & $(0.0426)$ & $(0.0427)$ \\
\hline \multirow[t]{2}{*}{ Large urban community } & $0.124 * * *$ & $0.110^{* * * *}$ & $-0.0997 * * *$ & $-0.0992 * * *$ & 0.0434 & 0.0459 & $0.163 * * *$ & $0.162 * * *$ & -0.0300 & -0.0411 & $0.164 * * *$ & $0.155 * * *$ \\
\hline & $(0.0408)$ & $(0.0412)$ & $(0.0360)$ & $(0.0362)$ & $(0.0443)$ & $(0.0448)$ & $(0.0492)$ & $(0.0497)$ & $(0.0335)$ & $(0.0338)$ & $(0.0473)$ & $(0.0476)$ \\
\hline No of observations & 15,559 & 15,559 & 15,559 & 15,559 & 15,559 & 15,559 & 15,559 & 15,559 & 15,559 & 15,559 & 15,559 & 15,559 \\
\hline
\end{tabular}

Note: clustered by country robust standard errors in brackets. $* * * 1 \%$ significance, $* * 5 \%$ significance, $* 10 \%$ significance 
Table 8.

Perceptions on different sources of energy: ML ordered probit estimation.

\begin{tabular}{|c|c|c|c|c|c|c|c|c|c|c|}
\hline & \multicolumn{2}{|c|}{ Coal } & \multicolumn{2}{|c|}{ Oil } & \multicolumn{2}{|c|}{ Gas } & \multicolumn{2}{|c|}{ Nuclear } & \multicolumn{2}{|c|}{ Hydro } \\
\hline & (1) & (2) & (1) & (2) & (1) & (2) & (1) & (2) & (1) & (2) \\
\hline Female & $0.108^{* * * *}$ & $0.110^{\text {**** }}$ & $0.112^{* * * *}$ & $0.120^{* * * *}$ & $-0.0552^{* * *}$ & $-0.0523^{* * * *}$ & $-0.351 * * *$ & $-0.339 * * *$ & $-0.124 * * *$ & $-0.134 * * *$ \\
\hline & $(0.0176)$ & $(0.0177)$ & $(0.0174)$ & $(0.0175)$ & $(0.0177)$ & $(0.0179)$ & $(0.0184)$ & $(0.0185)$ & $(0.0193)$ & $(0.0194)$ \\
\hline Age & -0.000385 & -0.000352 & $0.00572 * * *$ & $0.00609 * * *$ & $0.00506 * * *$ & $0.00528 * * *$ & $0.00167 * * *$ & $0.00169 * * *$ & 0.000835 & 0.000678 \\
\hline Children $<10$ & $\begin{array}{c}0.0139 \\
(0.0236)\end{array}$ & $\begin{array}{c}0.0111 \\
(0.0237)\end{array}$ & $\begin{array}{l}0.00133 \\
(0.0238)\end{array}$ & $\begin{array}{l}0.00318 \\
(0.0239)\end{array}$ & $\begin{array}{c}0.0128 \\
(0.0237)\end{array}$ & $\begin{array}{c}0.0152 \\
(0.0237)\end{array}$ & $\begin{array}{l}-0.0167 \\
(0.0247)\end{array}$ & $\begin{array}{l}-0.0186 \\
(0.0248)\end{array}$ & $\begin{array}{l}-0.0247 \\
(0.0260)\end{array}$ & $\begin{array}{l}-0.0235 \\
(0.0260)\end{array}$ \\
\hline Children 10-14 & $\begin{array}{l}0.00898 \\
(0.0270)\end{array}$ & $\begin{array}{l}0.00778 \\
(0.0271)\end{array}$ & $\begin{array}{c}0.0308 \\
(0.0264)\end{array}$ & $\begin{array}{c}0.0300 \\
(0.0264)\end{array}$ & $\begin{array}{l}-0.00368 \\
(0.0263)\end{array}$ & $\begin{array}{l}-0.00324 \\
(0.0263)\end{array}$ & $\begin{array}{c}-0.0901 * * * * \\
(0.0272)\end{array}$ & $\begin{array}{c}-0.0922 * * * \\
(0.0273)\end{array}$ & $\begin{array}{c}-0.0351 \\
(0.0291)\end{array}$ & $\begin{array}{l}-0.0328 \\
(0.0292)\end{array}$ \\
\hline Years of education & $\begin{array}{c}-0.0144 * * * * \\
(0.00187)\end{array}$ & $\begin{array}{c}-0.0140^{* * * *} \\
(0.00187)\end{array}$ & $\begin{array}{c}-0.00876 * * * \\
(0.00175)\end{array}$ & $\begin{array}{c}-0.00777 * * * * \\
(0.00175)\end{array}$ & $\begin{array}{c}-0.000254 \\
(0.00185)\end{array}$ & $\begin{array}{l}0.000153 \\
(0.00186)\end{array}$ & $\begin{array}{c}0.00514 * * * \\
(0.00188)\end{array}$ & $\begin{array}{c}0.00553 * * * \\
(0.00189)\end{array}$ & $\begin{array}{c}0.00269 \\
(0.00203)\end{array}$ & $\begin{array}{c}0.00235 \\
(0.00203)\end{array}$ \\
\hline Agriculture & $\begin{array}{c}0.0142 \\
(0.0850)\end{array}$ & $\begin{array}{c}0.0117 \\
(0.0851)\end{array}$ & $\begin{array}{c}0.110 \\
(0.0858)\end{array}$ & $\begin{array}{c}0.115 \\
(0.0857)\end{array}$ & $\begin{array}{c}-0.117 \\
(0.0990)\end{array}$ & $\begin{array}{c}-0.109 \\
(0.0990)\end{array}$ & $\begin{array}{c}0.0169 \\
(0.0965)\end{array}$ & $\begin{array}{l}4.25 \mathrm{e}-05 \\
(0.0969)\end{array}$ & $\begin{array}{l}-0.0629 \\
(0.0970)\end{array}$ & $\begin{array}{c}-0.0484 \\
(0.0970)\end{array}$ \\
\hline Professional & $\begin{array}{c}-0.128^{*} \\
(0.0669)\end{array}$ & $\begin{array}{l}-0.123 * \\
(0.0669)\end{array}$ & $\begin{array}{l}-0.120^{*} \\
(0.0666)\end{array}$ & $\begin{array}{l}-0.0983 \\
(0.0662)\end{array}$ & $\begin{array}{l}0.00611 \\
(0.0630)\end{array}$ & $\begin{array}{c}0.0180 \\
(0.0630)\end{array}$ & $\begin{array}{l}-0.173 * * \\
(0.0722)\end{array}$ & $\begin{array}{l}-0.171^{* * *} \\
(0.0722)\end{array}$ & $\begin{array}{l}0.143 * * \\
(0.0718)\end{array}$ & $\begin{array}{l}0.146 * * \\
(0.0717)\end{array}$ \\
\hline Self employed & $\begin{array}{c}-0.0786^{*} \\
(0.0411)\end{array}$ & $\begin{array}{c}-0.0809^{* * *} \\
(0.0413)\end{array}$ & $\begin{array}{c}-0.119 * * * \\
(0.0433)\end{array}$ & $\begin{array}{c}-0.109^{* * *} \\
(0.0435)\end{array}$ & $\begin{array}{l}-0.0201 \\
(0.0416)\end{array}$ & $\begin{array}{c}-0.00755 \\
(0.0418)\end{array}$ & $\begin{array}{c}0.0386 \\
(0.0447)\end{array}$ & $\begin{array}{c}0.0228 \\
(0.0449)\end{array}$ & $\begin{array}{c}0.0365 \\
(0.0462)\end{array}$ & $\begin{array}{c}0.0526 \\
(0.0464)\end{array}$ \\
\hline Employed professional & $\begin{array}{l}-0.0550^{*} \\
(0.0302)\end{array}$ & $\begin{array}{l}-0.0534^{*} \\
(0.0305)\end{array}$ & $\begin{array}{c}-0.0818^{* * *} * \\
(0.0299)\end{array}$ & $\begin{array}{c}-0.0614 * * \\
(0.0301)\end{array}$ & $\begin{array}{c}0.0331 \\
(0.0306)\end{array}$ & $\begin{array}{c}0.0476 \\
(0.0310)\end{array}$ & $\begin{array}{c}0.0145 \\
(0.0315)\end{array}$ & $\begin{array}{c}0.0106 \\
(0.0318)\end{array}$ & $\begin{array}{c}0.0269 \\
(0.0344)\end{array}$ & $\begin{array}{c}0.0352 \\
(0.0348)\end{array}$ \\
\hline Services & $\begin{array}{l}-0.0157 \\
(0.0246)\end{array}$ & $\begin{array}{l}-0.0146 \\
(0.0247)\end{array}$ & $\begin{array}{c}0.0136 \\
(0.0239)\end{array}$ & $\begin{array}{c}0.0287 \\
(0.0241)\end{array}$ & $\begin{array}{l}0.0425^{*} \\
(0.0238)\end{array}$ & $\begin{array}{l}0.0526^{* * *} \\
(0.0240)\end{array}$ & $\begin{array}{c}-0.0887 * * * * 6 \\
(0.0246)\end{array}$ & $\begin{array}{c}-0.0903 * * * * \\
(0.0248)\end{array}$ & $\begin{array}{c}0.0279 \\
(0.0260)\end{array}$ & $\begin{array}{c}0.0325 \\
(0.0261)\end{array}$ \\
\hline Manual Worker & $\begin{array}{c}0.0776^{* * * *} \\
(0.0299)\end{array}$ & $\begin{array}{c}0.0749 * * \\
(0.0300)\end{array}$ & $\begin{array}{c}0.103 * * * \\
(0.0298)\end{array}$ & $\begin{array}{c}0.106 * * * \\
(0.0300)\end{array}$ & $\begin{array}{c}0.0608 * * \\
(0.0302)\end{array}$ & $\begin{array}{c}0.0658 * * \\
(0.0303)\end{array}$ & $\begin{array}{l}-0.0336 \\
(0.0309)\end{array}$ & $\begin{array}{l}-0.0427 \\
(0.0310)\end{array}$ & $\begin{array}{c}0.0193 \\
(0.0328)\end{array}$ & $\begin{array}{c}0.0280 \\
(0.0329)\end{array}$ \\
\hline Paying lodging & $\begin{array}{c}0.0184 \\
(0.0236)\end{array}$ & $\begin{array}{c}0.0156 \\
(0.0237)\end{array}$ & $\begin{array}{c}0.0368 \\
(0.0234)\end{array}$ & $\begin{array}{l}0.0418^{*} \\
(0.0235)\end{array}$ & $\begin{array}{c}0.0607 * * \\
(0.0237)\end{array}$ & $\begin{array}{c}0.0643 * * * \\
(0.0239)\end{array}$ & $\begin{array}{c}0.0135 \\
(0.0247)\end{array}$ & $\begin{array}{l}0.00579 \\
(0.0249)\end{array}$ & $\begin{array}{l}-0.0118 \\
(0.0257)\end{array}$ & $\begin{array}{l}-0.00740 \\
(0.0259)\end{array}$ \\
\hline Paid lodging & $\begin{array}{c}0.0312 \\
(0.0243)\end{array}$ & $\begin{array}{c}0.0276 \\
(0.0244)\end{array}$ & $\begin{array}{c}0.0236 \\
(0.0242)\end{array}$ & $\begin{array}{c}0.0239 \\
(0.0243)\end{array}$ & $\begin{array}{l}-0.0247 \\
(0.0243)\end{array}$ & $\begin{array}{l}-0.0240 \\
(0.0245)\end{array}$ & $\begin{array}{c}0.0276 \\
(0.0256)\end{array}$ & $\begin{array}{c}0.0187 \\
(0.0258)\end{array}$ & $\begin{array}{c}0.000748 \\
(0.0265)\end{array}$ & $\begin{array}{l}0.00786 \\
(0.0267)\end{array}$ \\
\hline Computer & $\begin{array}{c}-0.0358 \\
(0.0311)\end{array}$ & $\begin{array}{c}-0.0317 \\
(0.0311)\end{array}$ & $\begin{array}{c}-0.0693 * * \\
(0.0307)\end{array}$ & $\begin{array}{l}-0.0577^{*} \\
(0.0307)\end{array}$ & $\begin{array}{c}-0.0742^{* *} \\
(0.0312)\end{array}$ & $\begin{array}{c}-0.0699^{* *} \\
(0.0312)\end{array}$ & $\begin{array}{l}0.0670^{* *} * \\
(0.0325)\end{array}$ & $\begin{array}{c}0.0733^{* *} * \\
(0.0325)\end{array}$ & $\begin{array}{c}0.0352 \\
(0.0337)\end{array}$ & $\begin{array}{c}0.0299 \\
(0.0338)\end{array}$ \\
\hline Internet & $\begin{array}{c}-0.0773 * * * * \\
(0.0296)\end{array}$ & $\begin{array}{c}-0.0778^{* * *} * \\
(0.0296)\end{array}$ & $\begin{array}{l}-0.0304 \\
(0.0294)\end{array}$ & $\begin{array}{l}-0.0306 \\
(0.0294)\end{array}$ & $\begin{array}{c}0.0382 \\
(0.0296)\end{array}$ & $\begin{array}{c}0.0383 \\
(0.0296)\end{array}$ & $\begin{array}{c}0.0474 \\
(0.0308)\end{array}$ & $\begin{array}{c}0.0463 \\
(0.0307)\end{array}$ & $\begin{array}{c}0.0502 \\
(0.0323)\end{array}$ & $\begin{array}{c}0.0509 \\
(0.0323)\end{array}$ \\
\hline Cut heating & & $\begin{array}{c}-0.0398 * * \\
(0.0186)\end{array}$ & & $\begin{array}{c}-0.0894 * * * \\
(0.0184)\end{array}$ & & $\begin{array}{c}-0.0554 * * * \\
(0.0187)\end{array}$ & & $\begin{array}{c}-0.0441^{* *} \\
(0.0194)\end{array}$ & & $\begin{array}{c}0.0615 * * * \\
(0.0204)\end{array}$ \\
\hline Cut lightning & & $\begin{array}{l}0.00476 \\
(0.0181)\end{array}$ & & $\begin{array}{c}-0.0555^{* * * *} \\
(0.0179)\end{array}$ & & $\begin{array}{l}-0.0164 \\
(0.0183)\end{array}$ & & $\begin{array}{c}-0.0863 * * * \\
(0.0190)\end{array}$ & & $\begin{array}{c}0.0538 * * * \\
(0.0199)\end{array}$ \\
\hline Insulated house & & $\begin{array}{c}0.0301 \\
(0.0226)\end{array}$ & & $\begin{array}{l}-0.0109 \\
(0.0223)\end{array}$ & & $\begin{array}{r}-0.00447 \\
(0.0229)\end{array}$ & & $\begin{array}{l}0.0565^{* *} \\
(0.0232)\end{array}$ & & $\begin{array}{c}-0.0372 \\
(0.0246)\end{array}$ \\
\hline Saved energy & & $\begin{array}{r}-0.00470 \\
(0.0328)\end{array}$ & & $\begin{array}{c}-0.0964 * * * \\
(0.0317)\end{array}$ & & $\begin{array}{c}-0.0810^{* * *} \\
(0.0325)\end{array}$ & & $\begin{array}{c}0.0453 \\
(0.0345)\end{array}$ & & $\begin{array}{r}-0.100 * * * * \\
(0.0357)\end{array}$ \\
\hline Less car & & $\begin{array}{l}-0.0193 \\
(0.0197)\end{array}$ & & $\begin{array}{c}-0.0529 * * * \\
(0.0193)\end{array}$ & & $\begin{array}{l}-0.0231 \\
(0.0197)\end{array}$ & & $\begin{array}{l}0.00876 \\
(0.0203)\end{array}$ & & $\begin{array}{c}0.0181 \\
(0.0215)\end{array}$ \\
\hline More public transport & & $\begin{array}{c}-0.0527 * * \\
(0.0254)\end{array}$ & & $\begin{array}{c}-0.0482^{*} \\
(0.0247)\end{array}$ & & $\begin{array}{c}0.0282 \\
(0.0252)\end{array}$ & & $\begin{array}{c}-0.107 * * * \\
(0.0263)\end{array}$ & & $\begin{array}{c}0.0662 * * \\
(0.0275)\end{array}$ \\
\hline Small urban community & 0.0228 & 0.0267 & -0.0205 & -0.0184 & $0.0579 * * *$ & $0.0570^{* * * *}$ & 0.0194 & 0.0257 & 0.0250 & 0.0196 \\
\hline
\end{tabular}




\begin{tabular}{|c|c|c|c|c|c|c|c|c|c|c|}
\hline & $(0.0208)$ & $(0.0209)$ & $(0.0204)$ & $(0.0205)$ & $(0.0207)$ & $(0.0207)$ & $(0.0213)$ & $(0.0213)$ & $(0.0227)$ & $(0.0227)$ \\
\hline Large urban community & $\begin{array}{c}-0.0476 \text { ** } \\
(0.0232)\end{array}$ & $\begin{array}{c}-0.0406^{*} \\
(0.0233)\end{array}$ & $\begin{array}{l}-0.0280 \\
(0.0227)\end{array}$ & $\begin{array}{l}-0.0225 \\
(0.0229)\end{array}$ & $\begin{array}{c}0.110 * * * \\
(0.0232)\end{array}$ & $\begin{array}{l}0.108 * * * \\
(0.0234)\end{array}$ & $\begin{array}{c}0.0395 \\
(0.0243)\end{array}$ & $\begin{array}{c}0.0540 * * \\
(0.0245)\end{array}$ & $\begin{array}{l}-0.0262 \\
(0.0255)\end{array}$ & $\begin{array}{l}-0.0364 \\
(0.0257)\end{array}$ \\
\hline Number of observations & 14,791 & 14,791 & 15,084 & 15,084 & 14,992 & 14,992 & 14,657 & 14,657 & 13,960 & 13,960 \\
\hline
\end{tabular}

Note: clustered by country robust standard errors in brackets. $* * * 1 \%$ significance, $* * 5 \%$ significance, $* 10 \%$ significance

Table 8 (continued): Perceptions on different sources of energy: ML ordered probit estimation

\begin{tabular}{|c|c|c|c|c|c|c|c|c|}
\hline & \multicolumn{2}{|c|}{ Biomass } & \multicolumn{2}{|c|}{ Wind } & \multicolumn{2}{|c|}{ Solar } & \multicolumn{2}{|c|}{ Ocean } \\
\hline & (1) & (2) & (1) & (2) & (1) & (2) & (1) & (2) \\
\hline Female & $\begin{array}{c}-0.0665^{* * *} * \\
(0.0190)\end{array}$ & $\begin{array}{c}-0.0772^{* * *} \\
(0.0191)\end{array}$ & $\begin{array}{c}0.0532 * * * * \\
(0.0196)\end{array}$ & $\begin{array}{l}0.0373^{*} \\
(0.0197)\end{array}$ & $\begin{array}{l}0.00147 \\
(0.0206)\end{array}$ & $\begin{array}{l}-0.0159 \\
(0.0207)\end{array}$ & $\begin{array}{c}-0.0411^{* *} \\
(0.0198)\end{array}$ & $\begin{array}{c}-0.0520^{* * * *} \\
(0.0199)\end{array}$ \\
\hline Age & $\begin{array}{c}0.00315^{* * *} * \\
(0.000655)\end{array}$ & $\begin{array}{c}0.00265^{* * * *} \\
(0.000661)\end{array}$ & $\begin{array}{c}-0.00166^{* * *} \\
(0.000674)\end{array}$ & $\begin{array}{c}-0.00206 * * * \\
(0.000680)\end{array}$ & $\begin{array}{c}0.000237 \\
(0.000716)\end{array}$ & $\begin{array}{c}-0.000374 \\
(0.000722)\end{array}$ & $\begin{array}{c}-0.000462 \\
(0.000674)\end{array}$ & $\begin{array}{r}-0.000680 \\
(0.000681)\end{array}$ \\
\hline Children $<10$ & $\begin{array}{l}-0.0420 \\
(0.0258)\end{array}$ & $\begin{array}{l}-0.0460^{*} \\
(0.0259)\end{array}$ & $\begin{array}{c}0.0402 \\
(0.0268)\end{array}$ & $\begin{array}{c}0.0413 \\
(0.0268)\end{array}$ & $\begin{array}{c}0.0261 \\
(0.0281)\end{array}$ & $\begin{array}{c}0.0250 \\
(0.0282)\end{array}$ & $\begin{array}{c}0.0199 \\
(0.0263)\end{array}$ & $\begin{array}{c}0.0212 \\
(0.0264)\end{array}$ \\
\hline Children 10-14 & $\begin{array}{l}-0.0235 \\
(0.0290)\end{array}$ & $\begin{array}{l}-0.0215 \\
(0.0291)\end{array}$ & $\begin{array}{c}0.0221 \\
(0.0299)\end{array}$ & $\begin{array}{c}0.0244 \\
(0.0300)\end{array}$ & $\begin{array}{l}0.00893 \\
(0.0314)\end{array}$ & $\begin{array}{c}0.0129 \\
(0.0315)\end{array}$ & $\begin{array}{c}-0.0166 \\
(0.0300)\end{array}$ & $\begin{array}{c}-0.0143 \\
(0.0300)\end{array}$ \\
\hline Years of education & $\begin{array}{c}0.00660 * * * * \\
(0.00200)\end{array}$ & $\begin{array}{c}0.00566 * * * \\
(0.00199)\end{array}$ & $\begin{array}{l}0.00373^{*} \\
(0.00214)\end{array}$ & $\begin{array}{c}0.00278 \\
(0.00214)\end{array}$ & $\begin{array}{l}0.00514 * * \\
(0.00229)\end{array}$ & $\begin{array}{l}0.00394 * \\
(0.00227)\end{array}$ & $\begin{array}{c}0.00639 * * * \\
(0.00222)\end{array}$ & $\begin{array}{l}0.00562 * * \\
(0.00222)\end{array}$ \\
\hline Agriculture & $\begin{array}{c}0.286 * * * \\
(0.0907)\end{array}$ & $\begin{array}{c}0.297 * * * \\
(0.0906)\end{array}$ & $\begin{array}{l}0.0795 \\
(0.108)\end{array}$ & $\begin{array}{c}0.102 \\
(0.108)\end{array}$ & $\begin{array}{c}-0.0136 \\
(0.110)\end{array}$ & $\begin{array}{c}0.00997 \\
(0.110)\end{array}$ & $\begin{array}{c}-0.0814 \\
(0.106)\end{array}$ & $\begin{array}{c}-0.0695 \\
(0.105)\end{array}$ \\
\hline Professional & $\begin{array}{l}0.175 * * \\
(0.0705)\end{array}$ & $\begin{array}{l}0.159 * * \\
(0.0707)\end{array}$ & $\begin{array}{c}0.0297 \\
(0.0773)\end{array}$ & $\begin{array}{c}0.0245 \\
(0.0766)\end{array}$ & $\begin{array}{l}0.193 * * \\
(0.0800)\end{array}$ & $\begin{array}{l}0.187 * * \\
(0.0795)\end{array}$ & $\begin{array}{l}0.172 * * \\
(0.0775)\end{array}$ & $\begin{array}{l}0.164 * * \\
(0.0770)\end{array}$ \\
\hline Self employed & $\begin{array}{c}0.129 * * * \\
(0.0452)\end{array}$ & $\begin{array}{c}0.137 * * * \\
(0.0455)\end{array}$ & $\begin{array}{c}0.0729 \\
(0.0481)\end{array}$ & $\begin{array}{l}0.0940^{*} \\
(0.0483)\end{array}$ & $\begin{array}{c}0.0306 \\
(0.0491)\end{array}$ & $\begin{array}{c}0.0531 \\
(0.0496)\end{array}$ & $\begin{array}{l}0.108 * * \\
(0.0468)\end{array}$ & $\begin{array}{l}0.119 * * \\
(0.0472)\end{array}$ \\
\hline Employed professional & $\begin{array}{c}0.0953 * * * * \\
(0.0332)\end{array}$ & $\begin{array}{c}0.0889 * * * \\
(0.0335)\end{array}$ & $\begin{array}{c}0.0380 \\
(0.0349)\end{array}$ & $\begin{array}{c}0.0413 \\
(0.0351)\end{array}$ & $\begin{array}{c}0.0785 * * \\
(0.0375)\end{array}$ & $\begin{array}{c}0.0859 * * \\
(0.0378)\end{array}$ & $\begin{array}{c}0.132 * * * \\
(0.0357)\end{array}$ & $\begin{array}{c}0.131 * * * * \\
(0.0360)\end{array}$ \\
\hline Services & $\begin{array}{c}0.0946 * * * \\
(0.0262)\end{array}$ & $\begin{array}{c}0.0896 * * * \\
(0.0263)\end{array}$ & $\begin{array}{c}0.113^{* * * *} \\
(0.0270)\end{array}$ & $\begin{array}{c}0.114 * * * * \\
(0.0272)\end{array}$ & $\begin{array}{c}0.0722 * * \\
(0.0285)\end{array}$ & $\begin{array}{c}0.0744 * * * * \\
(0.0288)\end{array}$ & $\begin{array}{c}0.109 * * * \\
(0.0268)\end{array}$ & $\begin{array}{c}0.107 * * * * \\
(0.0270)\end{array}$ \\
\hline Manual Worker & $\begin{array}{c}0.0355 \\
(0.0325)\end{array}$ & $\begin{array}{c}0.0379 \\
(0.0326)\end{array}$ & $\begin{array}{c}0.0531 \\
(0.0326)\end{array}$ & $\begin{array}{c}0.0649 * * \\
(0.0327)\end{array}$ & $\begin{array}{l}0.0620^{*} \\
(0.0339)\end{array}$ & $\begin{array}{c}0.0734 * * \\
(0.0340)\end{array}$ & $\begin{array}{c}0.0675 * * \\
(0.0329)\end{array}$ & $\begin{array}{l}0.0748^{* * *} \\
(0.0329)\end{array}$ \\
\hline Owns a car & $\begin{array}{c}0.0683 * * * \\
(0.0251)\end{array}$ & $\begin{array}{c}0.0539 \text { *** } \\
(0.0259)\end{array}$ & $\begin{array}{c}0.0924 * * * * \\
(0.0258)\end{array}$ & $\begin{array}{c}0.0841 * * * \\
(0.0266)\end{array}$ & $\begin{array}{l}0.117 * * * \\
(0.0269)\end{array}$ & $\begin{array}{c}0.0976 * * * * \\
(0.0276)\end{array}$ & $\begin{array}{c}0.0734 * * * \\
(0.0260)\end{array}$ & $\begin{array}{c}0.0736 * * * * \\
(0.0267)\end{array}$ \\
\hline Paying lodging & $\begin{array}{c}0.0248 \\
(0.0254)\end{array}$ & $\begin{array}{c}0.0164 \\
(0.0256)\end{array}$ & $\begin{array}{l}-0.0207 \\
(0.0263)\end{array}$ & $\begin{array}{l}-0.0168 \\
(0.0264)\end{array}$ & $\begin{array}{l}0.0483^{*} \\
(0.0276)\end{array}$ & $\begin{array}{l}0.0475^{*} \\
(0.0278)\end{array}$ & $\begin{array}{r}-0.0280 \\
(0.0262)\end{array}$ & $\begin{array}{c}-0.0256 \\
(0.0264)\end{array}$ \\
\hline Paid lodging & $\begin{array}{l}-0.00302 \\
(0.0262)\end{array}$ & $\begin{array}{l}-0.00774 \\
(0.0265)\end{array}$ & $\begin{array}{c}-0.0585 * * \\
(0.0274)\end{array}$ & $\begin{array}{l}-0.0489^{*} \\
(0.0276)\end{array}$ & $\begin{array}{l}-0.00492 \\
(0.0285)\end{array}$ & $\begin{array}{c}-0.000918 \\
(0.0287)\end{array}$ & $\begin{array}{c}-0.0392 \\
(0.0274)\end{array}$ & $\begin{array}{c}-0.0349 \\
(0.0275)\end{array}$ \\
\hline Computer & $\begin{array}{c}0.0192 \\
(0.0335)\end{array}$ & $\begin{array}{l}0.00768 \\
(0.0336)\end{array}$ & $\begin{array}{c}0.0163 \\
(0.0341)\end{array}$ & $\begin{array}{l}0.00285 \\
(0.0342)\end{array}$ & $\begin{array}{l}0.0593 * \\
(0.0353)\end{array}$ & $\begin{array}{c}0.0442 \\
(0.0354)\end{array}$ & $\begin{array}{c}0.0343 \\
(0.0346)\end{array}$ & $\begin{array}{c}0.0242 \\
(0.0347)\end{array}$ \\
\hline Internet & $\begin{array}{c}0.0449 \\
(0.0322)\end{array}$ & $\begin{array}{c}0.0446 \\
(0.0323)\end{array}$ & $\begin{array}{c}0.0410 \\
(0.0326)\end{array}$ & $\begin{array}{c}0.0424 \\
(0.0326)\end{array}$ & $\begin{array}{c}0.0677 * * * \\
(0.0340)\end{array}$ & $\begin{array}{c}0.0676^{* * *} \\
(0.0340)\end{array}$ & $\begin{array}{c}0.0522 \\
(0.0332)\end{array}$ & $\begin{array}{c}0.0526 \\
(0.0332)\end{array}$ \\
\hline Cut heating & & $\begin{array}{c}0.0822 * * * * \\
(0.0203)\end{array}$ & & $\begin{array}{c}0.110 * * * * \\
(0.0209)\end{array}$ & & $\begin{array}{c}0.146 * * * * \\
(0.0221)\end{array}$ & & $\begin{array}{c}0.0549^{* * * *} \\
(0.0209)\end{array}$ \\
\hline Cut lightning & & $\begin{array}{c}0.0778 * * * \\
(0.0197)\end{array}$ & & $\begin{array}{l}0.109 * * * * \\
(0.0202)\end{array}$ & & $\begin{array}{l}0.107 * * * * \\
(0.0213)\end{array}$ & & $\begin{array}{c}0.0744 * * * * \\
(0.0204)\end{array}$ \\
\hline
\end{tabular}


Table 8 (continued)

\begin{tabular}{|c|c|c|c|c|c|c|c|c|}
\hline \multicolumn{2}{|l|}{ Insulated house } & \multicolumn{2}{|l|}{$\begin{array}{c}0.0778 * * * \\
(0.0244)\end{array}$} & $\begin{array}{l}-0.0525 * * \\
(0.0252)\end{array}$ & \multicolumn{3}{|c|}{-0.00220} & $\begin{array}{l}-0.0122 \\
(0.0254\end{array}$ \\
\hline \multicolumn{2}{|l|}{ Saved energy } & \multirow{2}{*}{\multicolumn{2}{|c|}{$\begin{array}{l}-0.0526 \\
(0.0357)\end{array}$}} & $-0.0950 * * *$ & & \multicolumn{2}{|l|}{$\begin{array}{c}(0.0267) \\
-0.172 * * *\end{array}$} & -0.0355 \\
\hline \multirow{3}{*}{\multicolumn{2}{|c|}{ Less car }} & & & $(0.0366)$ & & \multicolumn{2}{|l|}{$(0.0395)$} & $(0.0376)$ \\
\hline & & \multirow{2}{*}{\multicolumn{2}{|c|}{$\begin{array}{c}0.0598 * * * \\
(0.0213)\end{array}$}} & $0.0611 * * *$ & & \multirow{2}{*}{\multicolumn{2}{|c|}{$\begin{array}{c}0.0899 * * * \\
(0.0234)\end{array}$}} & 0.0331 \\
\hline & & & & $(0.0222)$ & & & & $(0.0222)$ \\
\hline \multirow{2}{*}{\multicolumn{2}{|c|}{ More public transport }} & \multirow{2}{*}{\multicolumn{2}{|c|}{$\begin{array}{c}0.0780 * * * \\
(0.0277)\end{array}$}} & $0.121 * * *$ & & $0.121^{* * *}$ & & $0.127 * * *$ \\
\hline & & & & $(0.0284)$ & & $(0.0304)$ & & $(0.0285)$ \\
\hline \multirow{2}{*}{ Small urban community } & -0.0329 & -0.0343 & 0.0112 & 0.00362 & 0.0228 & 0.0157 & -0.00123 & -0.00583 \\
\hline & $(0.0222)$ & $(0.0223)$ & $(0.0229)$ & $(0.0230)$ & $(0.0239)$ & $(0.0241)$ & $(0.0230)$ & $(0.0230)$ \\
\hline \multirow[t]{2}{*}{ Large urban community } & $-0.118^{* * *}$ & $-0.125^{* * * *}$ & -0.0304 & $-0.0471^{*}$ & 0.00973 & -0.00520 & -0.0364 & $-0.0505^{*}$ \\
\hline & $(0.0248)$ & $(0.0250)$ & $(0.0260)$ & $(0.0262)$ & $(0.0271)$ & $(0.0274)$ & $(0.0259)$ & $(0.0261)$ \\
\hline Number of observations & 14,129 & 14,129 & 14,856 & 14,856 & 15,025 & 15,025 & 13,859 & 13,859 \\
\hline
\end{tabular}

Note: clustered by country robust standard errors in brackets. *** $1 \%$ significance, $* * 5 \%$ significance, $* 10 \%$ significance 
Table 9.

Perceptions on dominant fuel sources in the future: ML probit and ordered probit estimation.

\begin{tabular}{|c|c|c|c|c|c|c|}
\hline & \multicolumn{2}{|c|}{ Fossils (ordered probit) } & \multicolumn{2}{|c|}{ Renewable (ordered probit) } & \multicolumn{2}{|c|}{ Nuclear (probit) } \\
\hline & (1) & (2) & (1) & (2) & (1) & (2) \\
\hline (Intercept) & & & & & $\begin{array}{c}-1.625^{* * * *} \\
(0.0974)\end{array}$ & $\begin{array}{c}-1.637 \text { *** } \\
(0.0979)\end{array}$ \\
\hline Female & $\begin{array}{c}-0.0736 * * * \\
(0.0200)\end{array}$ & $\begin{array}{c}-0.0701 * * * \\
(0.0200)\end{array}$ & $\begin{array}{c}0.0714 * * * \\
(0.0180)\end{array}$ & $\begin{array}{c}0.0603^{* * * *} \\
(0.0181)\end{array}$ & $\begin{array}{c}-0.294 * * * \\
(0.0233)\end{array}$ & $\begin{array}{c}-0.295 * * * \\
(0.0234)\end{array}$ \\
\hline Age & $\begin{array}{c}0.000519 \\
(0.000676)\end{array}$ & $\begin{array}{c}0.000755 \\
(0.000682)\end{array}$ & $\begin{array}{c}-0.00578 * * * \\
(0.000619)\end{array}$ & $\begin{array}{c}-0.00657 * * * \\
(0.000626)\end{array}$ & $\begin{array}{c}0.00366 * * * \\
(0.000809)\end{array}$ & $\begin{array}{c}0.00371 \text { *** } \\
(0.000817)\end{array}$ \\
\hline Children $<10$ & $\begin{array}{l}-0.00551 \\
(0.0271)\end{array}$ & $\begin{array}{l}-0.00237 \\
(0.0272)\end{array}$ & $\begin{array}{l}-0.0125 \\
(0.0246)\end{array}$ & $\begin{array}{l}-0.0204 \\
(0.0246)\end{array}$ & $\begin{array}{l}-0.0113 \\
(0.0322)\end{array}$ & $\begin{array}{c}-0.00786 \\
(0.0323)\end{array}$ \\
\hline Children 10-14 & $\begin{array}{c}-0.0454 \\
(0.0308)\end{array}$ & $\begin{array}{l}-0.0452 \\
(0.0308)\end{array}$ & $\begin{array}{c}0.0295 \\
(0.0271)\end{array}$ & $\begin{array}{c}0.0317 \\
(0.0271)\end{array}$ & $\begin{array}{l}-0.0560 \\
(0.0362)\end{array}$ & $\begin{array}{l}-0.0546 \\
(0.0362)\end{array}$ \\
\hline Years of education & $\begin{array}{c}0.00427 * * \\
(0.00196)\end{array}$ & $\begin{array}{c}0.00433 * * \\
(0.00196)\end{array}$ & $\begin{array}{l}0.00339^{*} \\
(0.00181)\end{array}$ & $\begin{array}{c}0.00208 \\
(0.00182)\end{array}$ & $\begin{array}{c}0.0112 * * * \\
(0.00240)\end{array}$ & $\begin{array}{c}0.0107 * * * \\
(0.00240)\end{array}$ \\
\hline Agriculture & $\begin{array}{c}0.0312 \\
(0.0881)\end{array}$ & $\begin{array}{c}0.0295 \\
(0.0881)\end{array}$ & $\begin{array}{l}-0.0621 \\
(0.0853)\end{array}$ & $\begin{array}{l}-0.0548 \\
(0.0855)\end{array}$ & $\begin{array}{c}-0.334 * * * \\
(0.123)\end{array}$ & $\begin{array}{c}-0.331 \text { *** } \\
(0.123)\end{array}$ \\
\hline Professional & $\begin{array}{l}0.156 * * \\
(0.0681)\end{array}$ & $\begin{array}{l}0.157 * * \\
(0.0681)\end{array}$ & $\begin{array}{c}0.0355 \\
(0.0651)\end{array}$ & $\begin{array}{c}0.0147 \\
(0.0648)\end{array}$ & $\begin{array}{l}-0.179 * * \\
(0.0807)\end{array}$ & $\begin{array}{l}-0.187 * * \\
(0.0809)\end{array}$ \\
\hline Self employed & $\begin{array}{l}-0.0179 \\
(0.0459)\end{array}$ & $\begin{array}{l}-0.0203 \\
(0.0461)\end{array}$ & $\begin{array}{c}0.0464 \\
(0.0429)\end{array}$ & $\begin{array}{c}0.0460 \\
(0.0432)\end{array}$ & $\begin{array}{l}-0.00575 \\
(0.0554)\end{array}$ & $\begin{array}{l}-0.00597 \\
(0.0557)\end{array}$ \\
\hline Employed professional & $\begin{array}{c}0.134 * * * \\
(0.0356)\end{array}$ & $\begin{array}{c}0.131 * * * \\
(0.0359)\end{array}$ & $\begin{array}{l}-0.0379 \\
(0.0317)\end{array}$ & $\begin{array}{l}-0.0515 \\
(0.0320)\end{array}$ & $\begin{array}{c}0.0888 * * \\
(0.0403)\end{array}$ & $\begin{array}{c}0.0811^{* *} \\
(0.0408)\end{array}$ \\
\hline Services & $\begin{array}{l}0.0529 * \\
(0.0276)\end{array}$ & $\begin{array}{l}0.0519^{*} \\
(0.0278)\end{array}$ & $\begin{array}{c}0.0722^{* * * *} \\
(0.0246)\end{array}$ & $\begin{array}{c}0.0607^{* *} \\
(0.0248)\end{array}$ & $\begin{array}{l}-0.0438 \\
(0.0327)\end{array}$ & $\begin{array}{l}-0.0490 \\
(0.0330)\end{array}$ \\
\hline Manual Worker & $\begin{array}{c}-0.000273 \\
(0.0342)\end{array}$ & $\begin{array}{c}-0.000858 \\
(0.0342)\end{array}$ & $\begin{array}{c}0.0294 \\
(0.0307)\end{array}$ & $\begin{array}{c}0.0277 \\
(0.0308)\end{array}$ & $\begin{array}{c}-0.0417 \\
(0.0398)\end{array}$ & $\begin{array}{l}-0.0399 \\
(0.0399)\end{array}$ \\
\hline Owns a car & $\begin{array}{c}-0.00788 \\
(0.0261)\end{array}$ & $\begin{array}{c}-0.00150 \\
(0.0270)\end{array}$ & $\begin{array}{c}0.147 * * * \\
(0.0242)\end{array}$ & $\begin{array}{c}0.118 * * * \\
(0.0250)\end{array}$ & $\begin{array}{c}0.0956^{* * * *} \\
(0.0314)\end{array}$ & $\begin{array}{c}0.0961 * * * \\
(0.0325)\end{array}$ \\
\hline Paying lodging & $\begin{array}{l}0.00513 \\
(0.0270)\end{array}$ & $\begin{array}{l}0.00878 \\
(0.0271)\end{array}$ & $\begin{array}{l}0.0444^{*} \\
(0.0245)\end{array}$ & $\begin{array}{c}0.0333 \\
(0.0246)\end{array}$ & $\begin{array}{l}0.00594 \\
(0.0313)\end{array}$ & $\begin{array}{l}0.00778 \\
(0.0315)\end{array}$ \\
\hline Paid lodging & $\begin{array}{c}0.0363 \\
(0.0271)\end{array}$ & $\begin{array}{c}0.0375 \\
(0.0272)\end{array}$ & $\begin{array}{c}0.0309 \\
(0.0249)\end{array}$ & $\begin{array}{c}0.0269 \\
(0.0249)\end{array}$ & $\begin{array}{c}0.0410 \\
(0.0318)\end{array}$ & $\begin{array}{c}0.0424 \\
(0.0320)\end{array}$ \\
\hline Computer & $\begin{array}{c}-0.00981 \\
(0.0342)\end{array}$ & $\begin{array}{c}-0.00852 \\
(0.0342)\end{array}$ & $\begin{array}{c}0.102 * * * \\
(0.0316)\end{array}$ & $\begin{array}{c}0.0872 \text { *** } \\
(0.0316)\end{array}$ & $\begin{array}{c}-0.0113 \\
(0.0419)\end{array}$ & $\begin{array}{c}-0.0174 \\
(0.0420)\end{array}$ \\
\hline Internet & $\begin{array}{c}-0.00238 \\
(0.0330)\end{array}$ & $\begin{array}{c}-0.00234 \\
(0.0330)\end{array}$ & $\begin{array}{c}-0.00941 \\
(0.0304)\end{array}$ & $\begin{array}{c}-0.00996 \\
(0.0304)\end{array}$ & $\begin{array}{c}0.176 * * * \\
(0.0396)\end{array}$ & $\begin{array}{c}0.176 * * * \\
(0.0397)\end{array}$ \\
\hline Cut heating & & $\begin{array}{c}-0.0571 * * * \\
(0.0213)\end{array}$ & & $\begin{array}{c}0.113 * * * \\
(0.0191)\end{array}$ & & $\begin{array}{c}-0.000151 \\
(0.0246)\end{array}$ \\
\hline Cut lightning & & $\begin{array}{l}-0.0225 \\
(0.0207)\end{array}$ & & $\begin{array}{c}0.116 * * * \\
(0.0187)\end{array}$ & & $\begin{array}{c}0.0114 \\
(0.0241)\end{array}$ \\
\hline Insulated house & & $\begin{array}{c}-0.0186 \\
(0.0259)\end{array}$ & & $\begin{array}{c}0.0729 \text { *** } \\
(0.0231)\end{array}$ & & $\begin{array}{c}-0.0161 \\
(0.0296)\end{array}$ \\
\hline Saved energy & & $\begin{array}{c}0.0587 \\
(0.0374)\end{array}$ & & $\begin{array}{l}-0.0186 \\
(0.0346)\end{array}$ & & $\begin{array}{c}0.0674 \\
(0.0435)\end{array}$ \\
\hline Less car & & $\begin{array}{l}-0.00715 \\
(0.0226)\end{array}$ & & $\begin{array}{c}0.0963^{* * * *} \\
(0.0203)\end{array}$ & & $\begin{array}{c}0.0252 \\
(0.0260)\end{array}$ \\
\hline More public transport & & $\begin{array}{c}0.0386 \\
(0.0278)\end{array}$ & & $\begin{array}{c}0.0224 \\
(0.0253)\end{array}$ & & $\begin{array}{c}0.101 * * * \\
(0.0329)\end{array}$ \\
\hline Said fossils fuels & $\begin{array}{c}0.885 * * * \\
(0.0565)\end{array}$ & $\begin{array}{c}0.892 * * * \\
(0.0568)\end{array}$ & $\begin{array}{c}0.537 * * * \\
(0.0400)\end{array}$ & $\begin{array}{c}0.512 * * * \\
(0.0400)\end{array}$ & $\begin{array}{c}0.378 * * * \\
(0.0515)\end{array}$ & $\begin{array}{c}0.371 * * * \\
(0.0517)\end{array}$ \\
\hline Said renewables & $\begin{array}{c}-0.177 * * * \\
(0.0221)\end{array}$ & $\begin{array}{c}-0.176^{* * *} * \\
(0.0221)\end{array}$ & $\begin{array}{c}0.511 * * * \\
(0.0204)\end{array}$ & $\begin{array}{c}0.503 * * * \\
(0.0204)\end{array}$ & $\begin{array}{l}0.0443^{*} \\
(0.0267)\end{array}$ & $\begin{array}{c}0.0407 \\
(0.0267)\end{array}$ \\
\hline Said nuclear & $\begin{array}{l}-0.0320 \\
(0.0281)\end{array}$ & $\begin{array}{l}-0.0321 \\
(0.0281)\end{array}$ & $\begin{array}{c}0.140 * * * \\
(0.0249)\end{array}$ & $\begin{array}{c}0.133 * * * \\
(0.0250)\end{array}$ & $\begin{array}{c}0.562 * * * \\
(0.0299)\end{array}$ & $\begin{array}{c}0.558 * * * \\
(0.0299)\end{array}$ \\
\hline Small urban community & $\begin{array}{c}0.0949 * * * \\
(0.0239)\end{array}$ & $\begin{array}{c}0.0947 * * * \\
(0.0239)\end{array}$ & $\begin{array}{c}-0.0456^{* *} \\
(0.0211)\end{array}$ & $\begin{array}{c}-0.0450 * * \\
(0.0212)\end{array}$ & $\begin{array}{c}0.0937 \text { *** } \\
(0.0272)\end{array}$ & $\begin{array}{c}0.0895 * * * \\
(0.0273)\end{array}$ \\
\hline Large urban community & $\begin{array}{c}0.136 * * * \\
(0.0259) \\
\end{array}$ & $\begin{array}{c}0.133 * * * \\
(0.0261) \\
\end{array}$ & $\begin{array}{c}-0.109 * * * \\
(0.0235)\end{array}$ & $\begin{array}{c}-0.111 * * * \\
(0.0238)\end{array}$ & $\begin{array}{c}0.121 * * * \\
(0.0309)\end{array}$ & $\begin{array}{c}0.109 * * * \\
(0.0311)\end{array}$ \\
\hline Number of observations & 15,559 & 15,559 & 15,559 & 15,559 & 15,559 & 15,559 \\
\hline
\end{tabular}

Note: clustered by country robust standard errors in brackets. *** $1 \%$ significance, $* * 5 \%$ significance, $* 10 \%$ significance 
Table 10.

Trust to institutions on energy matters: ML ordered probit estimation.

\begin{tabular}{|c|c|c|c|c|c|c|c|c|c|c|c|c|c|c|c|c|}
\hline & \multicolumn{2}{|c|}{ National government } & \multicolumn{2}{|c|}{$\begin{array}{c}\text { Regional/local } \\
\text { government }\end{array}$} & \multicolumn{2}{|c|}{$\mathbf{E U}$} & \multicolumn{2}{|c|}{ Utilities } & \multicolumn{2}{|c|}{ Scientists } & \multicolumn{2}{|c|}{$\begin{array}{c}\text { Environmental } \\
\text { protection agencies }\end{array}$} & \multicolumn{2}{|c|}{ Journalists } & \multicolumn{2}{|c|}{ Political parties } \\
\hline & (1) & (2) & (1) & (2) & (1) & (2) & (1) & (2) & (1) & (2) & (1) & (2) & (1) & (2) & (1) & (2) \\
\hline & 0.024 & 0.022 & -0.01 & -0.012 & $0.047 * *$ & $0.046^{* * *}$ & $-0.073 * * *$ & $-0.078 * * *$ & $0.035^{*}$ & $0.046 * *$ & $-0.111 * * *$ & $-0.099 * * *$ & 0.001 & $2.10^{-4}$ & -0.016 & -0.02 \\
\hline \multirow[t]{2}{*}{ Female } & $(0.019)$ & $(0.019)$ & $(0.019)$ & $(0.019)$ & $(0.019)$ & $(0.019)$ & $(0.019)$ & $(0.019)$ & $(0.019)$ & $(0.019)$ & $(0.019)$ & $(0.019)$ & $(0.019)$ & (0.019) & $(0.019)$ & (0.019) \\
\hline & -0.001 & -0.001 & $2.10^{-4}$ & $2.10^{-4}$ & $0.002 * *$ & $0.002^{* * *}$ & 0.001 & 0.001 & $0.001 *$ & $0.002^{* * *}$ & $0.002 * * *$ & $0.003 * * *$ & $2.10^{-4}$ & $2.10^{-4}$ & 0.001 & 0.001 \\
\hline \multirow[t]{2}{*}{ Age } & $(0.001)$ & $(0.001)$ & $(0.001)$ & $(0.001)$ & $(0.001)$ & $(0.001)$ & $(0.001)$ & $(0.001)$ & $(0.001)$ & $(0.001)$ & $(0.001)$ & $(0.001)$ & $(0.001)$ & $(0.001)$ & $(0.001)$ & $(0.001)$ \\
\hline & $-0.079 * * *$ & $-0.078 * * *$ & $-0.048^{*}$ & $-0.047^{*}$ & -0.022 & -0.021 & -0.023 & -0.021 & 0.011 & 0.011 & -0.02 & -0.019 & $-0.066^{* * * *}$ & $-0.064 * *$ & -0.033 & -0.03 \\
\hline \multirow[t]{2}{*}{ Children $<10$} & $(0.025)$ & $(0.025)$ & $(0.025)$ & $(0.026)$ & $(0.026)$ & $(0.026)$ & $(0.025)$ & $(0.025)$ & $(0.026)$ & $(0.026)$ & $(0.026)$ & $(0.026)$ & $(0.025)$ & $(0.025)$ & $(0.026)$ & $(0.026)$ \\
\hline & -0.011 & -0.01 & 0.003 & 0.004 & -0.023 & -0.023 & -0.004 & -0.001 & -0.032 & -0.034 & -0.032 & -0.036 & 0.02 & 0.021 & -0.009 & -0.006 \\
\hline \multirow[t]{2}{*}{ Children 10-14 } & $(0.028)$ & $(0.028)$ & $(0.028)$ & $(0.028)$ & $(0.028)$ & $(0.028)$ & $(0.028)$ & $(0.028)$ & $(0.029)$ & $(0.029)$ & $(0.028)$ & $(0.028)$ & $(0.028)$ & $(0.028)$ & $(0.029)$ & $(0.029)$ \\
\hline & $-0.003 * * *$ & $-0.003 * * *$ & $-0.003 * * *$ & $-0.003^{* * * *}$ & $-0.004 * * *$ & $-0.004 * * *$ & $-0.001 * *$ & $-0.001 * *$ & $-0.002 * * *$ & $-0.002 * * *$ & $-0.002 * * *$ & $-0.002 * * *$ & $-0.002 * * *$ & $-0.002 * * *$ & $-0.003 * * *$ & $-0.003 * * *$ \\
\hline \multirow[t]{2}{*}{ Years education } & $(0.001)$ & $(0.001)$ & $(0.001)$ & $(0.001)$ & $(0.001)$ & $(0.001)$ & $(0.001)$ & $(0.001)$ & $(0.001)$ & $(0.001)$ & $(0.001)$ & $(0.001)$ & $(0.001)$ & $(0.001)$ & $(0.001)$ & $(0.001)$ \\
\hline & -0.086 & -0.073 & -0.065 & -0.056 & -0.008 & 0.005 & -0.031 & -0.024 & 0.128 & 0.119 & 0.297 ***** & $0.291^{* * * *}$ & 0.021 & 0.03 & $-0.158^{*}$ & -0.139 \\
\hline \multirow[t]{2}{*}{ Agriculture } & $(0.092)$ & $(0.092)$ & $(0.093)$ & $(0.093)$ & $(0.093)$ & $(0.093)$ & $(0.091)$ & $(0.091)$ & (0.094) & $(0.094)$ & $(0.091)$ & $(0.091)$ & $(0.091)$ & $(0.091)$ & $(0.092)$ & $(0.092)$ \\
\hline & 0.018 & 0.031 & 0.034 & 0.039 & $-0.188 * * *$ & $-0.168^{* * *}$ & $0.246 * * *$ & $0.234 * * *$ & -0.102 & -0.089 & -0.097 & -0.072 & $-0.234 * * *$ & $-0.226^{* * *}$ & 0.077 & 0.084 \\
\hline \multirow{2}{*}{ Professional } & $(0.068)$ & $(0.068)$ & $(0.068)$ & $(0.068)$ & $(0.069)$ & $(0.069)$ & $(0.068)$ & $(0.068)$ & $(0.069)$ & $(0.069)$ & $(0.068)$ & $(0.068)$ & $(0.068)$ & $(0.068)$ & $(0.069)$ & $(0.069)$ \\
\hline & 0.039 & 0.055 & $0.087^{*}$ & $0.097 * *$ & -0.024 & -0.008 & $0.128 * * *$ & $0.134 * * *$ & -0.014 & -0.021 & -0.001 & -0.004 & -0.061 & -0.05 & 0.05 & 0.071 \\
\hline \multirow[t]{2}{*}{ Self employed } & $(0.045)$ & $(0.045)$ & $(0.045)$ & $(0.045)$ & $(0.046)$ & $(0.046)$ & $(0.045)$ & $(0.045)$ & $(0.046)$ & $(0.046)$ & $(0.045)$ & $(0.046)$ & $(0.045)$ & $(0.045)$ & $(0.046)$ & $(0.046)$ \\
\hline & $-0.168 * * *$ & $-0.152 * * *$ & $-0.132 * * *$ & $-0.124 * * *$ & $-0.181 * * *$ & $-0.16^{* * * *}$ & $0.096^{* * * *}$ & $0.091 * * *$ & $-0.149 * * *$ & $-0.144 * * *$ & $-0.14 * * *$ & $-0.124 * * *$ & $-0.132 * * *$ & $-0.121 * * *$ & $-0.112 * * *$ & $-0.097^{* * *}$ \\
\hline \multirow[t]{2}{*}{ Employed professional } & $(0.034)$ & $(0.034)$ & $(0.034)$ & $(0.034)$ & $(0.034)$ & $(0.034)$ & $(0.034)$ & $(0.034)$ & $(0.034)$ & $(0.035)$ & $(0.034)$ & $(0.034)$ & $(0.034)$ & $(0.034)$ & $(0.034)$ & $(0.035)$ \\
\hline & $-0.111^{* * * *}$ & $-0.101^{* * * *}$ & $-0.086^{* * * *}$ & $-0.081^{* * *}$ & $-0.094 * * *$ & $-0.079 * * *$ & 0.011 & 0.007 & -0.044 & -0.041 & $-0.105^{* * * *}$ & $-0.093 * * *$ & $-0.122 * * *$ & $-0.115^{* * * *}$ & $-0.089 * * * *$ & $-0.079^{* * *}$ \\
\hline \multirow[t]{2}{*}{ Services } & $(0.027)$ & $(0.028)$ & $(0.027)$ & $(0.028)$ & $(0.028)$ & $(0.028)$ & $(0.027)$ & $(0.028)$ & $(0.028)$ & $(0.028)$ & $(0.028)$ & $(0.028)$ & $(0.027)$ & $(0.028)$ & $(0.028)$ & $(0.028)$ \\
\hline & -0.019 & -0.013 & -0.026 & -0.021 & -0.016 & -0.009 & $2.10^{-4}$ & 0.005 & 0.048 & 0.042 & -0.02 & -0.025 & -0.028 & -0.023 & $-0.064 *$ & -0.054 \\
\hline \multirow[t]{2}{*}{ Manual Worker } & $(0.033)$ & $(0.033)$ & $(0.033)$ & $(0.033)$ & $(0.033)$ & $(0.033)$ & $(0.033)$ & $(0.033)$ & $(0.033)$ & $(0.033)$ & $(0.033)$ & $(0.033)$ & $(0.033)$ & $(0.033)$ & $(0.033)$ & $(0.033)$ \\
\hline & -0.015 & -0.02 & -0.018 & -0.019 & -0.015 & -0.011 & 0.019 & 0.01 & 0.02 & 0.018 & 0.002 & 0.013 & 0.038 & $0.052^{* * *}$ & 0.006 & -0.001 \\
\hline Owns a car & $(0.025)$ & $(0.025)$ & $(0.025)$ & $(0.025)$ & $(0.025)$ & $(0.026)$ & $(0.025)$ & $(0.025)$ & $(0.025)$ & $(0.026)$ & $(0.025)$ & $(0.026)$ & $(0.025)$ & $(0.025)$ & $(0.025)$ & $(0.026)$ \\
\hline & $-0.06 * *$ & -0.055 & $-0.055^{* *}$ & $-0.053^{* * *}$ & $-0.058^{* *}$ & $-0.052 * *$ & $-0.05 * *$ & $-0.048^{*}$ & -0.037 & -0.036 & -0.028 & -0.027 & -0.009 & -0.007 & 0.003 & 0.01 \\
\hline Paying lodging & $(0.025)$ & $(0.025)$ & $(0.025)$ & $(0.025)$ & $(0.025)$ & $(0.025)$ & $(0.025)$ & $(0.025)$ & $(0.025)$ & $(0.026)$ & $(0.025)$ & $(0.025)$ & $(0.025)$ & $(0.025)$ & $(0.026)$ & $(0.026)$ \\
\hline & $-0.107 * * *$ & -0.101 & $-0.095^{* * *}$ & $-0.093^{* * *}$ & $-0.086^{* * *}$ & $-0.08 * * *$ & $-0.108 * * *$ & $-0.105^{* * * *}$ & $-0.064 * *$ & $-0.066^{* * *}$ & 0.001 & -0.002 & -0.037 & -0.037 & -0.042 & -0.035 \\
\hline Paid lodging & $(0.026)$ & $(0.026)$ & $(0.026)$ & $(0.026)$ & $(0.026)$ & $(0.026)$ & $(0.025)$ & $(0.026)$ & $(0.026)$ & $(0.026)$ & $(0.026)$ & $(0.026)$ & $(0.025)$ & $(0.026)$ & $(0.026)$ & $(0.026)$ \\
\hline & 0.01 & 0.012 & 0.039 & 0.038 & -0.048 & -0.042 & 0.008 & -0.003 & -0.006 & 0.003 & -0.014 & 0.006 & 0.025 & 0.027 & 0.021 & 0.016 \\
\hline Computer & $(0.032)$ & $(0.032)$ & $(0.032)$ & $(0.032)$ & $(0.033)$ & $(0.033)$ & $(0.032)$ & $(0.032)$ & $(0.033)$ & $(0.033)$ & $(0.032)$ & $(0.032)$ & $(0.032)$ & $(0.032)$ & $(0.033)$ & $(0.033)$ \\
\hline & -0.032 & -0.032 & -0.017 & -0.017 & $-0.058^{*}$ & $-0.057 *$ & $0.087^{* * * *}$ & $0.086 * * *$ & $-0.12 * * *$ & $-0.12 * * * *$ & $-0.065^{* * *}$ & $-0.065 * *$ & -0.018 & -0.017 & -0.016 & -0.016 \\
\hline Internet & $(0.031)$ & $(0.031)$ & $(0.031)$ & $(0.031)$ & $(0.031)$ & $(0.031)$ & $(0.031)$ & $(0.031)$ & $(0.031)$ & $(0.031)$ & $(0.031)$ & $(0.031)$ & $(0.031)$ & $(0.031)$ & $(0.032)$ & $(0.032)$ \\
\hline Cut heating & & -0.014 & & 0.008 & & -0.013 & & $0.058 * * *$ & & $-0.075^{* * *}$ & & $-0.088 * * *$ & & -0.019 & & 0.025 \\
\hline Cut hitating & & $(0.02)$ & & $(0.02)$ & & $(0.02)$ & & $(0.02)$ & & $(0.02)$ & & $(0.02)$ & & $(0.02)$ & & $(0.02)$ \\
\hline Cut lighting & & 0.033 & & 0.011 & & 0.005 & & 0.026 & & $-0.071^{* * * *}$ & & $-0.108 * * *$ & & 0.004 & & 0.024 \\
\hline & & $(0.019)$ & & $(0.019)$ & & $(0.019)$ & & $(0.019)$ & & $(0.02)$ & & $(0.019)$ & & $(0.019)$ & & $(0.02)$ \\
\hline Insulated house & & -0.04 & & -0.01 & & $-0.044 *$ & & -0.018 & & -0.01 & & -0.003 & & 0.005 & & -0.04 \\
\hline & & $(0.024)$ & & $(0.024)$ & & $(0.024)$ & & $(0.024)$ & & $(0.024)$ & & $(0.024)$ & & $(0.024)$ & & $(0.024)$ \\
\hline Saved energy & & -0.117 & & $-0.072 * *$ & & $-0.133 * * *$ & & -0.008 & & 0.014 & & -0.028 & & $-0.07 * *$ & & $-0.139 * * *$ \\
\hline & & $(0.035)$ & & $(0.035)$ & & $(0.035)$ & & $(0.035)$ & & $(0.036)$ & & $(0.036)$ & & $(0.035)$ & & $(0.036)$ \\
\hline Less car & & 0.022 & & 0.009 & & -0.013 & & $0.05 * *$ & & -0.007 & & $-0.069 * * *$ & & $-0.04 *$ & & $0.042 * *$ \\
\hline Lesocal & & $(0.021)$ & & $(0.021)$ & & $(0.021)$ & & $(0.021)$ & & $(0.021)$ & & $(0.021)$ & & $(0.021)$ & & $(0.021)$ \\
\hline
\end{tabular}


Table 10 (continued)

\begin{tabular}{|c|c|c|c|c|c|c|c|c|c|c|c|c|c|c|c|c|}
\hline More public transport & & $\begin{array}{c}-0.011 \\
(0.026)\end{array}$ & & $\begin{array}{c}0.027 \\
(0.026)\end{array}$ & & $\begin{array}{l}-0.032 \\
(0.027)\end{array}$ & & $\begin{array}{c}0.096 * * * \\
(0.026)\end{array}$ & & $\begin{array}{c}-0.094 * * * \\
(0.027)\end{array}$ & & $\begin{array}{c}-0.136 * * * \\
(0.027)\end{array}$ & & $\begin{array}{l}0.043^{*} \\
(0.026)\end{array}$ & & $\begin{array}{l}0.07 * * \\
(0.027)\end{array}$ \\
\hline Small urban community & $\begin{array}{l}-0.024 \\
(0.022)\end{array}$ & $\begin{array}{l}-0.025 \\
(0.022)\end{array}$ & $\begin{array}{c}0.002 \\
(0.022)\end{array}$ & $\begin{array}{c}0 \\
(0.022)\end{array}$ & $\begin{array}{c}-0.054 * * \\
(0.022)\end{array}$ & $\begin{array}{c}-0.055^{* * *} \\
(0.022)\end{array}$ & $\begin{array}{l}-0.014 \\
(0.022)\end{array}$ & $\begin{array}{c}-0.02 \\
(0.022)\end{array}$ & $\begin{array}{c}-0.076 * * * * \\
(0.022)\end{array}$ & $\begin{array}{c}-0.072 * * * \\
(0.022)\end{array}$ & $\begin{array}{l}-0.1 * * * \\
(0.022)\end{array}$ & $\begin{array}{c}-0.095 * * * \\
(0.022)\end{array}$ & $\begin{array}{c}-0.079 * * * \\
(0.022)\end{array}$ & $\begin{array}{c}-0.08 * * * \\
(0.022)\end{array}$ & $\begin{array}{l}-0.015 \\
(0.022)\end{array}$ & $\begin{array}{c}-0.02 \\
(0.022)\end{array}$ \\
\hline Large urban community & $\begin{array}{c}-0.049^{* * *} \\
(0.024)\end{array}$ & $\begin{array}{c}-0.05 \\
(0.024)\end{array}$ & $\begin{array}{c}0.001 \\
(0.024)\end{array}$ & $\begin{array}{l}-0.003 \\
(0.025)\end{array}$ & $\begin{array}{c}-0.102 * * * \\
(0.025)\end{array}$ & $\begin{array}{c}-0.101 * * * \\
(0.025)\end{array}$ & $\begin{array}{c}0.024 \\
(0.024)\end{array}$ & $\begin{array}{c}0.012 \\
(0.024)\end{array}$ & $\begin{array}{l}-0.123 \\
(0.025)\end{array}$ & $\begin{array}{c}-0.112 * * * \\
(0.025)\end{array}$ & $\begin{array}{c}-0.119^{* * *} \\
(0.025)\end{array}$ & $\begin{array}{c}-0.105 * * * \\
(0.025)\end{array}$ & $\begin{array}{c}-0.108 * * * * \\
(0.024)\end{array}$ & $\begin{array}{c}-0.111 * * * * \\
(0.024)\end{array}$ & $\begin{array}{l}-0.042^{*} \\
(0.025)\end{array}$ & $\begin{array}{c}-0.051^{* *} \\
(0.025)\end{array}$ \\
\hline
\end{tabular}




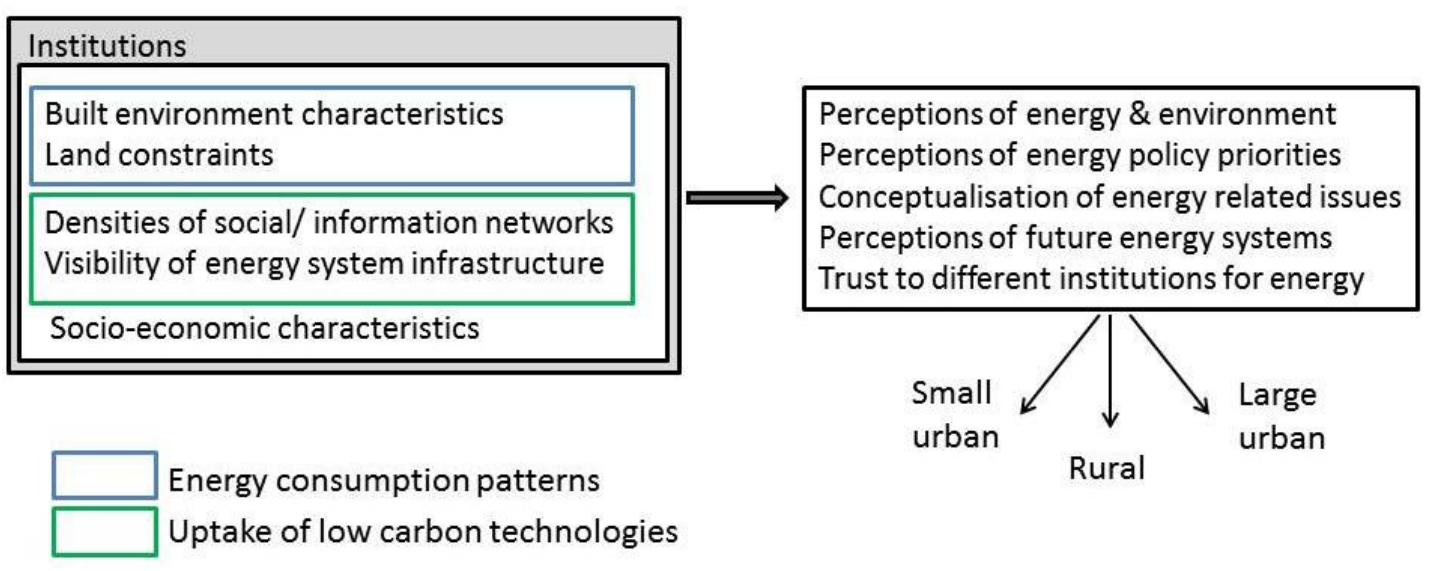

Fig. 1. Conceptual model of spatial factors influencing energy attitudes and perceptions 


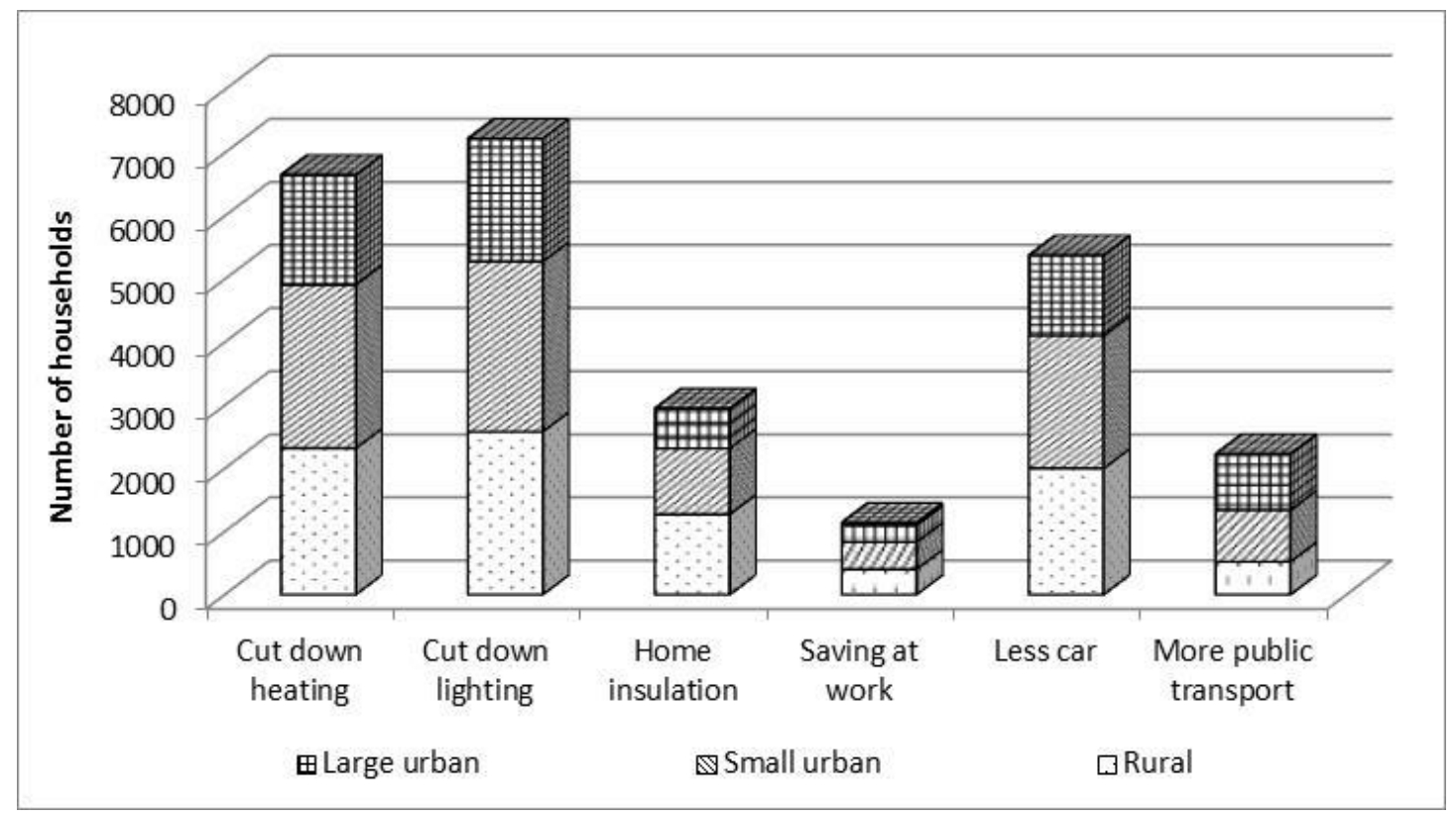

Fig. 2. Distribution of energy saving actions by geographical areas. 